\title{
Review Article \\ Genetic and Chromosomal Aberrations and Their Clinical Significance in Renal Neoplasms
}

\author{
Ning Yi Yap, ${ }^{1}$ Retnagowri Rajandram, ${ }^{1,2,3}$ Keng Lim Ng, ${ }^{1,2}$ Jayalakshmi Pailoor, \\ Ahmad Fadzli, ${ }^{1}$ and Glenda Carolyn Gobe ${ }^{2}$ \\ ${ }^{1}$ Department of Surgery, Faculty of Medicine, University of Malaya, Jalan Universiti, Kuala Lumpur, Malaysia \\ ${ }^{2}$ Centre for Kidney Disease Research, University of Queensland, Translational Research Institute, 37 Kent Street, \\ Brisbane QLD 4102, Australia \\ ${ }^{3}$ University of Malaya Cancer Research Institute, University of Malaya, Jalan Universiti, Kuala Lumpur, Malaysia \\ ${ }^{4}$ Department of Pathology, Faculty of Medicine, University of Malaya, Jalan Universiti, Kuala Lumpur, Malaysia
}

Correspondence should be addressed to Retnagowri Rajandram; rretnagowri@gmail.com

Received 23 January 2015; Revised 23 May 2015; Accepted 25 May 2015

Academic Editor: Konstantinos Arnaoutakis

Copyright (C) 2015 Ning Yi Yap et al. This is an open access article distributed under the Creative Commons Attribution License, which permits unrestricted use, distribution, and reproduction in any medium, provided the original work is properly cited.

The most common form of malignant renal neoplasms is renal cell carcinoma (RCC), which is classified into several different subtypes based on the histomorphological features. However, overlaps in these characteristics may present difficulties in the accurate diagnosis of these subtypes, which have different clinical outcomes. Genomic and molecular studies have revealed unique genetic aberrations in each subtype. Knowledge of these genetic changes in hereditary and sporadic renal neoplasms has given an insight into the various proteins and signalling pathways involved in tumour formation and progression. In this review, the genetic aberrations characteristic to each renal neoplasm subtype are evaluated along with the associated protein products and affected pathways. The potential applications of these genetic aberrations and proteins as diagnostic tools, prognostic markers, or therapeutic targets are also assessed.

\section{Introduction}

The incidence of kidney cancers has been increasing steadily in developed countries over the past decade and new reports show similar trends in developing countries [1-3]. Renal cell carcinoma (RCCs) form the majority of malignant kidney neoplasms and are grouped into a few different subtypes based on their histomorphological features. The most common subtype is clear cell RCC (ccRCC), followed by papillary (pRCC), chromophobe (chRCC), and collecting duct RCC (CDRCC). Renal oncocytoma (RO) is a benign renal neoplasm with histological similarities to chRCC [4]. Accurate identification of these subtypes is important for disease management as each subtype has a different biological and clinical behaviour. Cancer is often described as a genetic disease, caused by genetic alterations which regulate cell growth [5-7]. Hence, distinctive genetic aberrations in each RCC subtype affect the clinical course and prognosis of the tumour. The majority of RCCs are sporadic while only approximately $<3 \%$ are hereditary $[8,9]$. Although less frequently encountered, hereditary RCCs play a significant role in the understanding of genetic changes and pathways affecting tumour progression (Table 2).

Genetic alterations such as duplication, deletion, translocation, hypermethylation, or mutations result in the activation or inactivation of genes and the over- or underexpression of the corresponding proteins in RCCs. Genetics analysis helps in the identification of tumours in situations where histology and immunohistochemistry (IHC) profiles do not provide a clear distinction between the subtypes. Conventional methods for analysis include chromosomal comparative genomic hybridization (CGH), fluorescent in situ hybridization (FISH), G banding, and polymerase chain reaction (PCR) based loss of heterozygosity ( $\mathrm{LOH}$ ) analysis. Newer technologies such as array CGH (aCGH), single nucleotide polymorphisms (SNP) arrays, and next generation sequencing (NGS) have allowed for high throughput analyses 
of known aberrations as well as identification of novel genetic alterations.

In this review, the various genetic aberrations associated with familial and sporadic clear cell, papillary, chromophobe, collecting duct RCCs, and oncocytoma will be explored, along with the prognostic, diagnostic, and therapeutic implications of these genes.

\section{Clear Cell Renal Cell Carcinoma (ccRCC)}

Clear cell RCC is the most frequent subtype of renal cancer, accounting for $80-90 \%$ of all RCCs [10]. Originating from renal proximal tubules, ccRCC cells have abundant clear cytoplasm, a result of high glycogen and lipid content. Eosinophilic or granular cells may be present, due to a higher number of mitochondria [11]. Clear cell RCC has a metastatic rate of $15.3-21.5 \%$ at presentation and a 5 -year cancer specific survival of $71-81.3 \%$ [12-14].

2.1. Von Hippel-Lindau (VHL) Gene. The most common and characteristic genetic changes in ccRCCs are aberrations such as $\mathrm{LOH}$, hypermethylation, or mutation in $3 \mathrm{p}$ chromosome region, which are found in up to $91 \%$ of the tumours [15-17]. The VHL gene, a tumour suppressor gene (TSG) located at 3p25 loci, is one of the earlier genes associated with ccRCC. This gene was first discovered in patients with VHL disease, an autosomal dominant hereditary syndrome that predisposes affected individuals to cancers such as pheochromocytomas, hemangioblastomas, and ccRCC [18]. Up to $75 \%$ of patients with VHL syndrome develop ccRCC, a leading cause of death in these patients $[19,20]$. However, only approximately $1.6 \%$ of all ccRCC cases are associated with hereditary VHL syndrome [21]. Interest in VHL grew when the majority of sporadic ccRCC cases were also found to contain $V H L$ aberrations.

The VHL protein (pVHL) functions to ubiquitinate proteins and mark them for degradation, with hypoxia inducible factor $\alpha(\mathrm{HIF} \alpha)$ being a well-researched target involved in tumourigenesis [22-24]. HIF $\alpha$ is a transcription factor controlling angiogenesis, glucose uptake, cell proliferation, and apoptosis through downstream targets like vascular endothelial growth factor (VEGF), platelet-derived growth factor (PDGF), transforming growth factor alpha (TGF $\alpha$ ), and C-X-C chemokine receptor type 4 (CXCR4) [25-27]. Under normal oxygen conditions, HIF $\alpha$ is degraded by pVHL but when oxygen is low, HIF $\alpha$ is allowed to accumulate, inducing transcription of genes that improve cell proliferation, oxygen delivery, and angiogenesis [2224]. Inactivation of $V H L$, which occurs through mutation, deletion, or methylation, causes the accumulation of HIF $\alpha$ under normal oxygen conditions and encourages tumour growth. Individuals with VHL disease have one wild type VHL allele and one inactivated VHL allele [28]. According to the Knudson two-hit model, biallelic VHL inactivation is achieved when the remaining copy is inactivated by spontaneous mutation $[28,29]$. Sporadic renal tumours require spontaneous mutation of two wild type $V H L$ alleles [30].
VHL genetic changes are believed to be exclusively associated with ccRCC but van Houwelingen and colleagues have detected VHL mutations in 15\% of non-ccRCCs from a cohort of sporadic RCC patients in Netherlands. They noted that the percentage of patients with $V H L$ mutation was significantly higher for ccRCC compared to RCCs of other histological types [31]. Other studies however found no VHL mutation in other subtypes [32-34].

Inactivation of $V H L$ may play an important role in the pathogenesis of ccRCC, but the association of VHL status with clinicopathological parameters and disease progression is still unclear and contradictory. Some studies showed that the presence or absence of VHL alterations does not affect tumour stage, grade, or prognosis [35-37]. It has also been shown that there is no correlation between VHL mutation or methylation status with angiogenesis and proliferation of ccRCC $[35,38]$. Brauch et al. and Schraml et al. reported an association of tumour VHL alterations with advanced stage and adverse prognosis [35, 39]. In contrast, several other studies revealed favourable prognosis for tumours with $V H L$ inactivation or alteration [40-44]. These contradictory prognostic findings could be a result of complex transcriptional or posttranscriptional responses in addition to the various genetic aberrations which contribute to the heterogeneous characteristics of RCCs [35]. It is postulated that the VHL independent activation of other signal transduction pathways such as the mammalian target of rapamycin (mTOR), nuclear factor kappa-light-chain-enhancer of activated B cells (NF$\kappa \mathrm{B}$ ), signal transducer and activator of transcription 3 (STAT3), or epidermal growth factor receptor (EGFR) pathways could be responsible for tumour progression and tumours activated by several different mechanisms could be more aggressive [42]. Moreover, ccRCC tumours caused by VHL syndrome are of lower grade, less likely to metastasize, and have better 10-year survival compared to sporadic VHL RCCs, which may harbour other predisposing mutations [21].

Nevertheless, the discovery of the VHL gene in familial and sporadic ccRCC has revolutionised treatment for advanced RCC. Targeted therapy aiming at suppressing angiogenesis through VEGF or PDGF mediated pathways has replaced immunotherapy such as interferon alpha (IFN $\alpha$ ) and interleukin-2 (IL-2) as treatment for metastatic RCC. The current FDA approved targeted therapy drugs for RCC which are the tyrosine kinase inhibitors (sunitinib, sorafenib, pazopanib, and axitinib), monoclonal antibody to VEGF (bevacizumab), and the mTOR inhibitors (temsirolimus and everolimus) [45]. Targeted therapy has improved treatment outcome as the overall and cancer specific survival of metastatic RCC patients has improved in the targeted therapy era compared to the immunotherapy era $[46,47]$.

2.2. Chromosome 3 Translocations. A number of studies have reported hereditary ccRCC associated with translocation of chromosome 3, thus supporting the role of chromosome 3 in the pathogenesis of ccRCC. Cohen et al. (1979) first discovered a reciprocal translocation at $(3 ; 8)(\mathrm{p} 14.2 ; \mathrm{q} 24)$ in a family with hereditary ccRCC [48]. A possible gene of interest, FHIT, has been identified in that chromosome 3 region, which will be discussed in the next section. Since 
then, other constitutional translocations in chromosome 3 regions have been reported. These translocations such as $\mathrm{t}(1 ; 3)(\mathrm{q} 32 ; \mathrm{q} 13), \mathrm{t}(2 ; 3)(\mathrm{q} 33 ; \mathrm{q} 21), \mathrm{t}(2 ; 3)(\mathrm{q} 35 ; \mathrm{q} 21), \mathrm{t}(3 ; 6)(\mathrm{q} 12$; $\mathrm{q} 15)$, and $\mathrm{t}(3 ; 8)(\mathrm{p} 13 ; \mathrm{q} 24)$ were found in familial ccRCC [4954]. In some familial chromosome 3 translocations identified, $\mathrm{t}(3 ; 4)(\mathrm{p} 13 ; \mathrm{p} 16), \mathrm{t}(3 ; 4)(\mathrm{q} 21 ; \mathrm{q} 13), \mathrm{t}(3 ; 6)(\mathrm{p} 13 ; \mathrm{q} 25)$, and $\mathrm{t}(3 ; 15)$ (p11;q21), only one family member developed ccRCC [55-57]. The involvement of several TSG genes has been suggested, for example, $\mathrm{t}(1 ; 3)$ (q32;q13) (NORE1 and LSAMP), $\mathrm{t}(2 ; 3)$ (q33; q21) (DIRC1), t (2;3)(q35;q21) (DIRC2 and DIRC3), and $\mathrm{t}(3 ; 8)$ (p14.2;q24) (FHIT and TRC8). However, these translocations result from different breakpoints and some translocations had no identifiable breakpoint associated genes [52, 53, 58]. Hence, a three-step model has been proposed for familial chromosome 3 translocation ccRCC. The first step is inherited translocation of chromosome 3, followed by the loss of the $3 \mathrm{p}$ segment, and finally somatic mutation of the remaining $3 \mathrm{p}$ allele, which may contain the VHL gene or other TSGs located at $3 p[54,59]$.

2.3. Fragile Histidine Triad (FHIT). Although VHL plays a significant role in our understanding of ccRCC, it is not the only genetic aberration in chromosome $3 p$ region. In ccRCC with $3 p$ deletion with and without VHL alterations, inactivation of TSGs at 3p12-p21 appears to play a role in tumourigenesis $[33,60]$. Numerous studies have been carried out to identify potential TSGs along this region. One such gene is FHIT located in the 3p14.2 region. Chromosomal translocation at $\mathrm{t}(3 ; 8)(\mathrm{p} 14.2 ; \mathrm{q} 24)$ was first described in hereditary RCC and a common region of loss in chromosome 3 was found in sporadic ccRCC [61-64]. FHIT gene has been identified at this locus in several other malignancies including lung, breast, cervical, gastric, and bladder cancers [65-69]. The FHIT gene encompasses the chromosomal fragile site FRA3B, a frequently observed breakpoint in many cancers including RCC [70, 71]. As a result of inactivation, FHIT protein expression is low or absent in most ccRCC tumours [72-74].

The specific function of the FHIT protein is still unclear, but studies have demonstrated the role of the FHIT gene in tumour suppression. For example, there was an increase in formation of spontaneous tumours and susceptibility to carcinogen-induced tumours in FHIT knockout mice compared to mice with functional FHIT [75, 76]. There is a significant correlation between low or absence of FHIT protein expression and low grade and early stage ccRCC tumours indicating that LOH of FHIT may play a role in early tumour development [73, 74, 77, 78]. Interestingly, Ramp et al. reported that higher FHIT protein expression is linked to poorer patient survival and is an independent prognostic marker in ccRCCs [73]. Although FHIT is lower in ccRCC compared to normal kidney, higher FHIT levels in higher grade and stage tumours do not support the tumour suppressor function of FHIT [72-74]. Ramp et al. suggested that reversible epigenetic inactivation such as gene hypermethylation or posttranslational events may reactivate FHIT as the tumour progresses [73, 77]. However, there has yet to be conclusive evidence for these mechanisms.
2.4. Ras Association Domain Family 1A (RASSF1A). Another TSG associated with ccRCC in $3 p$ chromosome region is RASSF1A gene located at 3p21.3. RASS1A protein regulates microtubule formation, cell cycle control, and apoptosis [79]. Reintroduction of RASSF1A in lung and breast cancer cell lines inhibited cell cycle progression and proliferation [80]. RASS1A is inactivated by hypermethylation in the promoter region and this is frequently seen in ovarian, breast, and lung tumours, including ccRCC [81-83]. Peters et al. found significantly increased methylation in ccRCC tumours compared to normal tissues but also detected a subgroup of methylated sequences in the normal tissue [84]. The normal tissue was obtained from histologically benign region of the tumour bearing kidney, suggesting that hypermethylation of RASSF1A is involved in early tumour formation of RCC [84]. In ccRCC patients, hypermethylation of the RASSF1A promoter was significantly associated with advanced stage, higher grade, and unfavorable patient survival $[85,86]$. Tezval et al. reported that most ccRCC tumours have low RASS1A protein expression but a subset of tumours with increased expression is associated with higher stage and grade [87]. This is somewhat contradictory to the tumour suppressor function of the protein. More studies on protein expression of RASSF1A in ccRCC tumour tissue are needed to understand its effect on patient prognosis. Although less frequently reported, RASSF1A inactivation is also found in approximately $44 \%$ of papillary RCC [88].

2.5. Chromatin Modification Genes. Recently, NGS or exome sequencing studies have discovered several novel genes involved in chromatin modification which are mutated in ccRCC [89-91]. The newly identified genes are polybromo-1 (PBRM1), AT-rich interactive domain-containing protein $1 \mathrm{~A}$ (ARID1A), BRCA1 associated protein-1 (BAP1), SET domaincontaining 2 (SETD2), and lysine- (K-) specific demethylase 5C (KDM5C) [89-93]. PBRM1 mutations are found in up to $41 \%$ of ccRCC, making it the second most mutated gene after VHL [90]. PBRM1, BAP1, and SETD2 are all located near the 3 p 21 region and, similar to $V H L$, are proposed to be inactivated through the Knudson two-hit model [94]. As loss or deletion of $3 \mathrm{p}$ chromosome region is common in ccRCC, inactivation of these genes is achieved by further mutations in the remaining allele [90].

The discovery of these frequently mutated genes along with advances in NGS technology has led to interest in intratumour heterogeneity analysis in ccRCC. This provides an insight into the various mutations that may take part in tumour initiation or progression and possibly aid in fine tuning targeted therapy in the future. Multiple regions from a single tumour region were subjected to sequencing and mutations were mapped onto a phylogenic tree to illustrate the evolution of mutational events. Early or ubiquitous mutations are located at the trunk while subsequent or intratumour subclonal mutations are located at the branches. A ubiquitous mutation is found in all regions of a tumour analysed, whereas subclonal mutations are only found in a subpopulation of tumour cells $[94,95]$. 
VHL was mapped as a ubiquitous driver mutation in 64$100 \%$ of ccRCC tumours analysed by Gerlinger et al. and Sankin et al. [95, 96]. BAP1, PBRM1, SETD2, and KDM5C mutations were found in different subclones in the same tumour, indicating that these were later mutations $[95,96]$. However, $P B R M 1$ was also a ubiquitous mutation in $20-30 \%$ of ccRCC tumours analysed $[95,96]$. Sankin et al. reported an increased mutation frequency in intratumour multiregion analysis, compared to earlier large scale sequencing studies [96]. This was especially observed in nonubiquitous mutations, such as SETD and KDM5C [96]. They suggested that the actual mutation rate may be higher than reported in earlier studies, but this will have to be validated in a larger sample sized multiregion sequencing analysis. Although most studies have focused on mutations of these genes in sporadic ccRCC, germline $P B R M 1$ and $B A P 1$ mutations have been detected in familial ccRCC $[97,98]$. Germline BAP1 mutation also predisposes affected individuals to uveal melanoma, malignant pleural mesothelioma, and cutaneous melanoma [99].

These chromatin modification genes function as TSGs and have been implicated in other cancers, such as ARID1A and SETD2 in breast cancer and KDM5C in prostate cancer [100-102]. Alterations of the chromatin modification proteins could lead to disruptions of transcriptional regulation and tumour formation [92]. For example, silencing of PBRM1 in ccRCC cell lines increased proliferation and migration, supporting its role as a TSG [90]. In a RCC cell line with $B A P 1$ mutation, 769-P, cell proliferation was inhibited by the introduction of wild type BAP1 [91].

The roles of these chromatin modification genes and their proteins products are not fully understood yet, but various studies have shown that the mutational status of these genes may possess prognostic influence on ccRCC. Low PBRM1 expression was reported to correlate with advanced stage, higher Fuhrman grade, and worse disease specific survival [103, 104]. In contrast, Hakimi et al. and Sato et al. found no relationship between disease-free or disease specific survival and PBRM1 mutational status [105, 106]. BAP1 loss was associated with metastasis, advanced stage and Fuhrman grade, sarcomatoid differentiation, and worse overall and disease specific survival $[91,105,107,108]$. Compared to tumours exclusively mutated for $P B R M 1$, tumours with BAP1 only mutation conferred adverse clinicopathological features and prognosis $[109,110]$. Based on these findings, $B A P 1$ mutational status appears to be a strong prognostic indicator for ccRCC. Low ARID1A mRNA and BAF250a (protein product of ARID1A) levels also correlated with higher stage, grade, and worse prognosis while SETD2 mutation was associated with worse disease specific survival $[93,105,111]$.

2.6. Other Genetic Aberrations. Other genetic aberrations of interest, such as changes at chromosome regions $5 \mathrm{q}, 8 \mathrm{p}, 9 \mathrm{p}$, and 14, may affect the prognosis of ccRCC. Copy number gains at $5 \mathrm{q}$ conferred a favourable prognosis whereas a loss had an adverse effect [112-114]. LOH in $8 p, 9 p$, and $14 q$ has been associated with higher grade, stage, unfavourable prognosis, and tumour recurrence [115-121]. Potential candidate genes include CDK2NA (cyclin-dependent kinase inhibitor 2A) at 9p21 and HIF1A at $14 \mathrm{q} 23.2[118,119$, 121]. CDK2NA encodes the p16 tumour suppressor protein which plays an important role in cell cycle regulation by preventing cells progressing from G1 phase to $S$ phase [122].

Recent sequencing, transcriptome, and integrated data analyses have revealed frequently mutated signalling pathways in ccRCC such as the phosphoinositide 3-kinase PI3KAKT-mTOR and p53 pathways $[106,123]$. The PI3K-AKTmTOR pathway, which regulates angiogenesis, cell cycle progression, and proliferation, is a target for mTOR inhibitors temsirolimus and everolimus. Together, genes involved in the pathway, consisting of MTOR, PTEN, PIK3CA, AKT2, and others, have alterations in $26-28 \%$ of ccRCC tumours $[106,123]$. These findings provide concrete evidence on the genetic changes directly associated with the PI3K-AKTmTOR pathway in ccRCC. Targeted therapy with mTOR inhibitors in RCC was based on the understanding that elevated HIF could induce the PI3K/AKT pathway and promote angiogenesis [124]. Alterations of the genes found in the p53 signalling pathway, which includes TP53 and CDK2NA, could be detected in $40 \%$ of tumours [106]. The p53 pathway plays a role in apoptosis, inhibition of angiogenesis, and genomic stability. Knowledge in deregulated signalling pathways would help in providing patients with personalised targeted therapy and improving treatment outcome.

\section{Differential Diagnosis}

Clear Cell Tubulopapillary RCC. Clear cell tubulopapillary RCC is a recently identified RCC subtype comprising of cells with clear cytoplasm and papillary architecture. It is often reported in patients with end stage kidney disease but has been found in normal functioning kidneys and is typically low grade [125]. Although clear cell tubulopapillary RCC mimics ccRCC and pRCC histologically, it has a different genetic profile from both subtypes [126]. Clear cell tubulopapillary RCCs lack deletions of $3 p$ typical of ccRCC or gains of chromosome 7 and loss of chromosome Y characteristic of pRCC [126-128]. In addition, clear cell tubulopapillary RCC lacks VHL mutation commonly found in the ccRCC subtype [129].

\section{Papillary Renal Cell Carcinoma (pRCC)}

Papillary RCC is the second most common subtype, making up approximately $10 \%$ of all RCCs. Papillary RCC is characterised by tumour cells arranged in tubulopapillary architecture. Delahunt and Eble have proposed the subclassification of pRCCs into two histological groups, type 1 and type 2 [130]. Type 1 tumours are characterised by small cells with scant cytoplasm and small nuclei while type 2 tumours have large cells with plentiful eosinophilic cytoplasm and large spherical nuclei. Type 2 tumours are generally more aggressive, with more advanced grade and stage than type 1 tumours [130,131]. Compared to ccRCC, pRCCs have a better prognosis with a metastatic rate of 3.4-14.9\% at presentation and 5-year cancer specific survival of $79.4-91 \%$ [12-14]. 
3.1. Chromosomes 7 and 17. Papillary RCCs frequently display gains of chromosomes 7 and 17 [132-134]. Trisomies 7 and 17 discovered in small papillary renal cell neoplasia indicate that these genetic alterations may be involved in initial tumour development [135]. Based on past studies, polysomy 7 is not a reliable predictor of survival, stage, grade, or proliferation rate of papillary renal tumours [132, 133, 136, 137]. Polysomy 7 in ccRCC however was correlated with higher stage and grade [133]. The prognostic value of polysomy 17 in pRCC is contradictory. Balint et al. found no significant association between chromosome 17 gains and tumour grade or size [132]. In contrast, Gunawan et al. and Klatte et al. significantly correlated chromosome 17 polysomy with lower stage, less lymph node, and distant metastases, as well as a favourable survival $[137,138]$.

3.2. MET Protooncogene. At present, only one gene on chromosome 7 has been positively identified and linked to pRCC. Hereditary pRCC (HPRC) associated with type 1 tumours is caused by the mutation of the MET protooncogene at 7q31. An activating missense mutation of the MET gene and duplication of chromosome 7 along with the mutated MET gene were postulated to increase the oncogenic effect of $M E T$ $[139,140]$. MET mutation associated hereditary pRCC and sporadic pRCC are typically low grade, bilateral tumours with multiple lesions $[8,9,141]$. The protein product of the MET gene is c-met, a hepatocyte growth factor receptor (HGFR). Binding of the hepatocyte growth factor (HGF) or c-met to the MET receptor induces several biological responses which promote oncogenesis, including cell motility, cell differentiation, proliferation, angiogenesis, and invasion [142]. The role of c-met in pRCC has not been clearly elucidated but in hereditary pRCC it is suggested that germline mutations of the $M E T$ gene promote proliferation, tubulogenesis, and tumour initiation [143].

MET mutation is estimated to be present in $5-21.6 \%$ of sporadic pRCC $[8,108,139,141]$. A recent study by Albiges et al. reported copy number gains of MET in $46 \%$ of type II pRCC and in $81 \%$ of type I pRCC [108]. The c-met protein is strongly expressed in $80-90 \%$ of pRCC, indicating a role of MET copy number gains in protein activation $[108,143,144]$. Interestingly, there is no significant difference between c-met expressions in type 1 and type 2 pRCC although tumours with MET mutations favour the type 1 histology $[141,143,144]$. Sweeney et al. found a significant correlation between c-met expression and higher tumour stage and a trend towards a favourable overall survival rate for patients with c-met negative tumours [143]. To date, no other studies have shown prognostic association of c-met protein or MET gene in pRCC. In contrast, c-met expression is lower in ccRCC but studies have shown significant correlation of positive cmet immunoreactivity with metastasis and higher grade and stage $[144,145]$. A recent study by Gibney et al. reported a correlation of higher c-met expression with higher grade and stage and worse disease specific survival in RCCs [146]. This may not be specific to pRCCs as they analysed all RCC subtypes, including a majority of ccRCC [146]. Regardless of the prognostic significance, the c-met signalling pathway appears to be an attractive target for pRCC. Phase II clinical trials of c-met pathway inhibitors, volitinib and foretinib, are currently ongoing for advanced pRCC [147, 148].

3.3. Fumarate Hydratase (FH). Besides MET mutation associated HPRC, another form of hereditary pRCC is found in the autosomal dominant syndrome, hereditary leiomyomatosis, and renal cell carcinoma (HLRCC). Affected individuals are predisposed to develop cutaneous leiomyomas, uterine fibroids, and type 2 pRCC [149]. Renal tumours in HLRCC patients are characteristically solitary and unilateral with a propensity for nodal or distant metastasis $[150,151]$. In rare cases, renal tumours are of collecting duct RCC histology $[149,152]$. Germline mutation of the $F H$ gene has been identified and mapped to chromosome 1q42-43 [152, 153]. Fumarate hydratase $(\mathrm{FH})$ protein is an enzyme responsible for converting fumarate to malate in the Krebs cycle. As a consequence of missense, frameshift, insertion/deletion, nonsense, or complete deletions of the $F H$ gene, enzymatic activity of FH is significantly decreased [154]. Loss of FH activity causes the accumulation of fumarate, which can act as a competitive inhibitor of HIF prolyl hydroxylase (HPH) [155]. HPH degrades hypoxia inducible factors (HIFs) in normoxia conditions; hence elevated levels of fumarate result in stabilization and accumulation of HIFs [155]. Elevated HIFs promote angiogenesis and tumour progression. Compared to $V H L$ and MET, mutation of $F H$ in sporadic RCC is very rare [156]. For example, according to the COSMIC (Catalogue of Somatic Mutations in Cancer) database, $\mathrm{FH}$ mutations were found in 3 out of 1383 renal tumours analysed [157].

3.4. Other Genetic Aberrations. Deletions are often found in chromosomes $\mathrm{X}$ and $\mathrm{Y}$ of pRCC tumours. The effects of these chromosomal losses in pRCC are not well documented in literature and no TSG has been identified yet. Only one study, by Jiang et al., has significantly linked losses of chromosome Xp with shorter patient survival [158]. Besides gains of chromosomes 7 and 17, gains of chromosomes 12, 16, and 20 and loss of chromosome $\mathrm{Y}$ have also been detected in renal papillary adenomas, suggesting that these chromosomal alterations may be involved in early neoplastic changes in pRCC $[159,160]$. Multiregion sequencing analysis confirmed that gains in chromosomes $7,12,16$, and 17 are ubiquitous early events in pRCC tumourigenesis [161]. BAP1, SETD2, ARID2, and the Nrf2 pathway genes (KEAP1, NHE2L2, and CUL3) were identified as pRCC driver mutations, often found in tumour subclones. ARID2 forms the subunit of the SWI/SNF chromatin-remodeling complex and is functionally related to ARID1A, while the NrF2 pathway protects cells against oxidative stress and regulates cell survival $[161,162]$. However, less than $10 \%$ of pRCC harboured these mutations [161]. Most genetic changes were in the form of somatic copy number alterations, which were predominantly copy number gains, but the genes associated with these copy number alterations have yet to be identified [161].

Other chromosomal aberrations in pRCC are as listed in Table 1. Among these, loss of $9 \mathrm{p}$ may be a promising prognostic marker as Gunawan et al. and Klatte et al. associated the loss with higher stage, lymph node involvement, and increased risk of death from pRCC [137, 138]. Allelic 


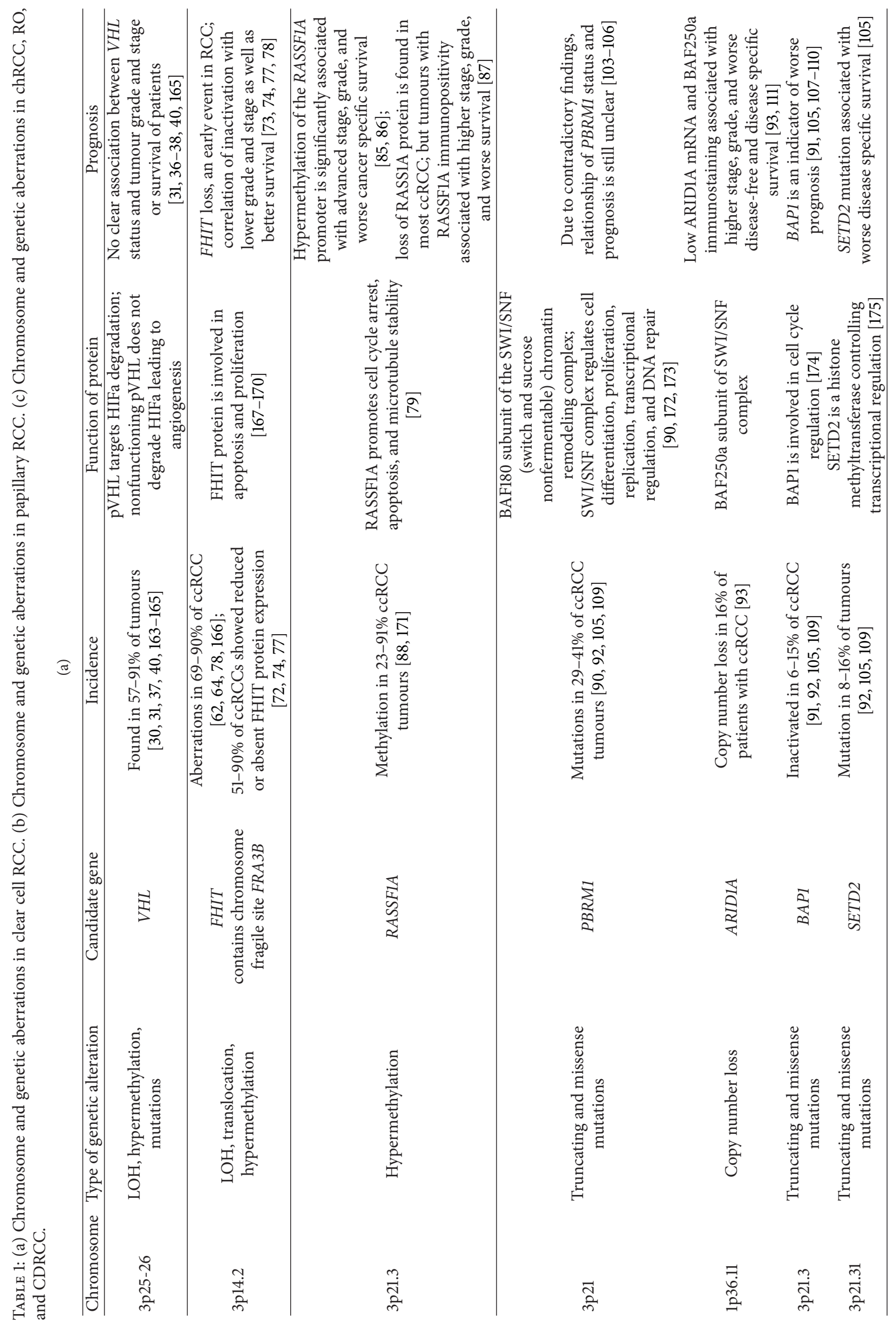




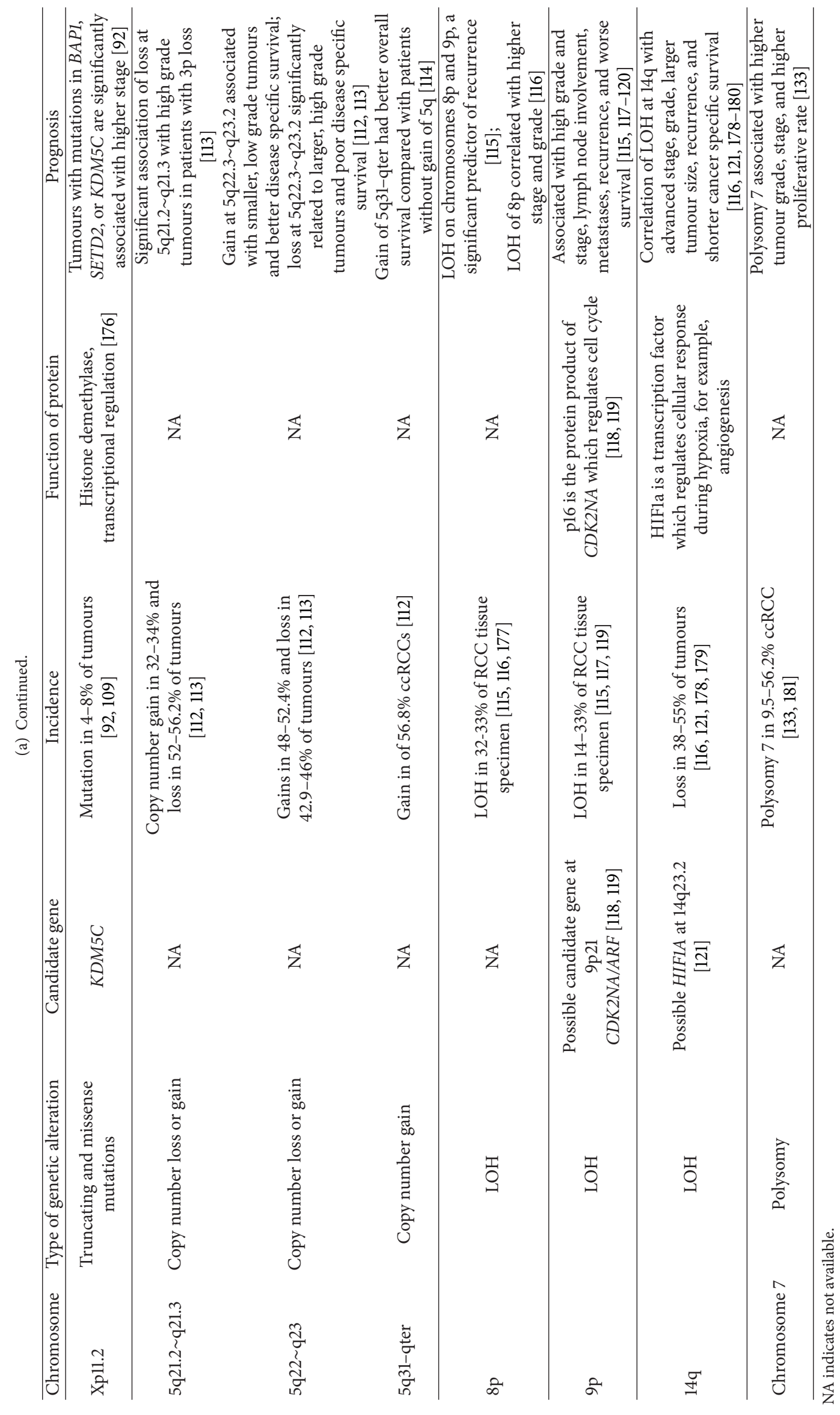




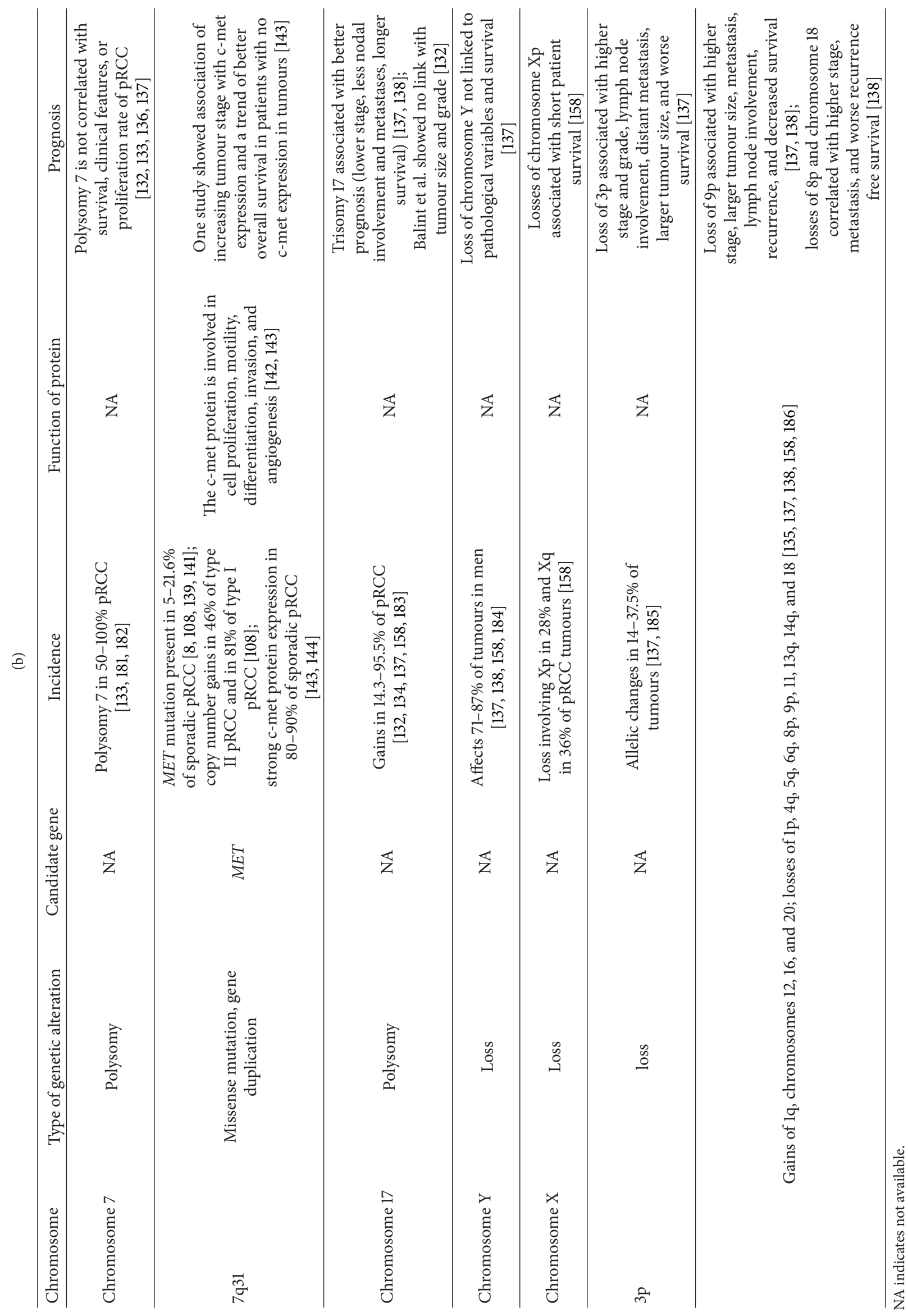




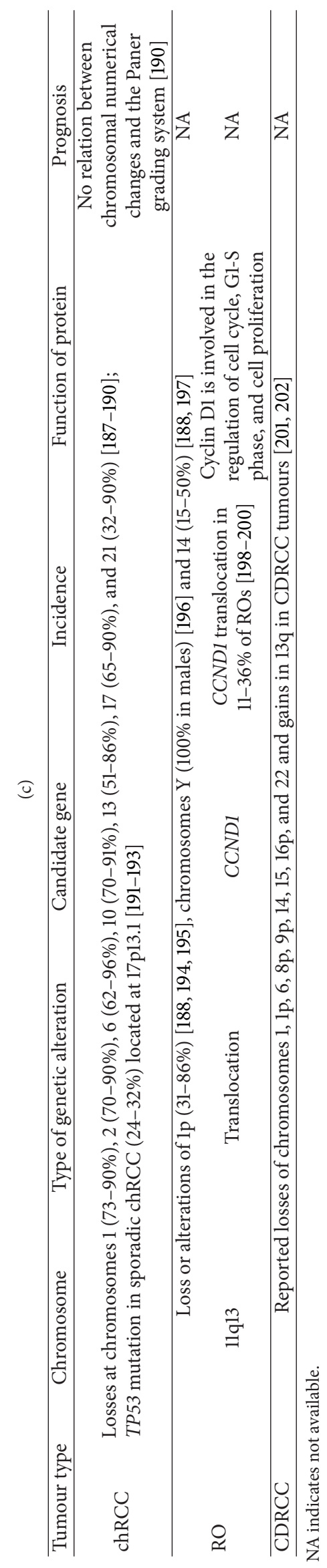


TABLE 2: Hereditary RCCs and their related genetic aberrations.

\begin{tabular}{|c|c|c|c|c|}
\hline Tumour type & Syndrome & Clinical manifestation & Chromosome & Candidate gene \\
\hline \multirow{2}{*}{ ccRCC } & $\begin{array}{l}\text { Von Hippel-Lindau } \\
\text { (VHL) }\end{array}$ & $\begin{array}{c}\text { Retinal, cerebellar and spinal } \\
\text { hemangioblastoma; pheochromocytoma; } \\
\text { pancreatic, epididymal and renal cysts; } \\
\text { hemangiomas of the adrenals, liver, and } \\
\text { lungs; endolymphatic sac tumours; } \\
\text { cystadenoma of the epididymis or broad } \\
\text { ligament and ccRCC }(40-75 \%)[19,20]\end{array}$ & $3 p 25$ & $V H L$ \\
\hline & $\begin{array}{l}\text { Constitutional } \\
\text { chromosome } 3 \\
\text { translocation }\end{array}$ & ccRCC & $\begin{array}{l}\text { Various } \\
\text { breakpoints in } \\
\text { chromosome } 3\end{array}$ & $\begin{array}{c}\text { Possible breakpoint } \\
\text { associated genes: } \\
\text { NORE1, LSAMP, DIRC1, } \\
\text { DIRC2, DIRC3, FHIT, } \\
\text { TRC8 } \\
\text { Possible known } \\
\text { common gene lost from } \\
\text { translocation: VHL }\end{array}$ \\
\hline \multirow[b]{2}{*}{ pRCC } & $\begin{array}{c}\text { Hereditary papillary } \\
\text { RCC (HPRC) }\end{array}$ & $\mathrm{pRCC}$ & $7 \mathrm{q} 31$ & MET \\
\hline & $\begin{array}{l}\text { Hereditary } \\
\text { leiomyomatosis and } \\
\text { RCC (HLRCC) }\end{array}$ & $\begin{array}{c}\text { Cutaneous leiomyomas, uterine fibroids, } \\
\text { type II } \\
\text { Renal tumours }(14-18 \%) \text { for example } \\
\text { pRCC and CDRCC }[149,152,154,203]\end{array}$ & $1 q 42-43$ & $F H$ \\
\hline chRCC or RO & Birt-Hogg-Dubé (BHD) & $\begin{array}{c}\text { Skin fibrofolliculomas, pulmonary cysts, } \\
\text { spontaneous pneumothorax, and renal } \\
\text { cancer (20-29\%) (chRCC, RO, ccRCC } \\
\text { and pRCC) [204-206] }\end{array}$ & $17 \mathrm{p} 11.2$ & $B H D, F L C N$ \\
\hline
\end{tabular}

alteration of $3 p$, which is characteristic of ccRCC, is also found in pRCC, although the incidence is lower $[137,185]$. Loss of $3 \mathrm{p}$ in $\mathrm{pRCC}$ was associated with worse prognosis such as higher $\mathrm{T}$ stage and grade, lymph node involvement, distant metastasis, larger tumour size, and worse survival [137].

\section{Differential Diagnosis}

(i) Type 1 and 2 pRCC. Besides histological differences, types 1 and 2 pRCC may have some distinguishable patterns of chromosome aberrations. Some studies showed no difference in polysomies 7 and 17 frequency in types 1 and 2 tumours $[132,135]$ but others reported higher frequency of chromosomes 7 and 17 gains in type 1 compared to type 2 [137, $138,158,184-186]$. Additionally, type 2 tumours have been shown to contain more chromosomal irregularities than type 1 tumours $[137,138,186]$. For example, type 2 tumours have a higher frequency of chromosomes $3 \mathrm{p}, 8$, and 18 losses and 1q, 2 , and $8 \mathrm{q}$ gains $[137,138,184,186]$. However, no specific chromosome marker that can distinguish the two pRCC types has been identified.

(ii) Metanephric Adenoma. Metanephric adenoma is a rare neoplasm of the kidney which has morphological similarities to pRCC. The tumours comprise of small basophilic cells arranged in a tubulopapillary pattern [207]. Most metanephric adenomas are benign with good prognosis but metastases have been reported in a few cases [208, 209]. Reports of chromosomes 7 and 17 gains and chromosome $\mathrm{Y}$ loss are conflicting in metanephric adenoma. Brown et al. found chromosomes 7 and 17 gains and sex chromosome loss in most of the 11 metanephric adenoma tumours analysed [210]. However, other more recent studies have reported no abnormalities in chromosomes 7, 17, X, or Y [207, 211, 212]. Brunelli et al. suggested that Brown et al. may have chosen a low threshold for chromosomal gains without normal tissue controls, resulting in the overestimation of chromosome gains [212]. Other genetic aberrations in metanephric adenoma are gains of chromosome 19 and deletions in chromosome 2 [211, 213-215].

Recently, an activating missense mutation in the $B R A F$ gene was discovered, which could be specific to metanephric adenoma $[215,216]$. The substitution of valine for glutamic acid in the BRAF gene results in the $\mathrm{V} 600 \mathrm{E}$ variant protein, which has increased activation potential compared to the wild type BRAF [216]. It is interesting to note that the BRAF gene is located at 7q34, but no other RCC subtypes show $B R A F$ mutation, except for one detection in a pRCC [216218]. The BRAF protein regulates the MAPK/ERK kinase pathway, promoting cell proliferation and cell survival [219]. Due to the benign nature of metanephric adenoma, the constitutive activation of the MAPK/ERK kinase pathway may be inhibited by p16, which is overexpressed in metanephric adenomas [216]. The p16 tumour suppressor protein was suggested to be activated as a self-limiting mechanism to the MAPK/ERK kinase pathway [216].

(iii) Clear Cell Tubulopapillary RCC. As mentioned previously, clear cell tubulopapillary RCC lacks gains in chromosomes 7 and 17 and loss of chromosome Y frequently found in pRCC [126]. 
(iv) Mucinous Tubular and Spindle Cell Carcinoma (MTSCC). Mucinous tubular and spindle cell carcinoma (MTSCC) is a newly recognized RCC subtype in the World Health Organization (WHO) 2004 classification [220]. The prognosis for MTSC is generally favourable as tumours are usually of low pathological stage at diagnosis [221]. It shares some immunohistochemical and histological features with pRCC, particularly the type 1 pRCC variants [221]. FISH analysis found no gains of chromosomes 7 and 17 and loss or chromosome $\mathrm{Y}$ in ten MTSCC tumours [222]. However, separate analyses by other groups showed gains in chromosomes 7 and/or 17 in their MTSCC cases [223-226]. Hence, chromosomes 7 and 17 status may not be suitable for differentiating pRCC and MTSCC. The loss of chromosome Y has only been reported in one MTSCC [226]. Other genetic alterations reported in MTSCC include losses of chromosomes 1, 4, 6, 8, 9, 13, 14, 15, and 22 [227].

(v) Xp11.2 Translocation RCC. This subtype, like MTSCC, was a new addition in the WHO 2004 classification [220]. Xp11.2 translocation RCCs predominantly affect children and adolescents but are found in adults as well [228]. Clinically aggressive metastatic cases have been reported [228, 229]. Xp11.2 translocation RCC cells have mixed papillary or nested structure and eosinophilic cytoplasm which may be mistaken for pRCC. Xp11.2 translocation RCCs are characterised and identified by balanced translocations of the transcription factor E3 (TFE3) gene on chromosome Xp11.2, resulting in gene fusions of the TFE3 gene [230, 231]. Depending on the breakpoint of the reciprocal gene, there are six known different TFE3 gene fusion combinations [230]. The gene fusions lead to overexpression of TFE3 protein and immunoreactivity with TFE3 protein is a distinguishing feature of Xp11.2 translocation RCCs [232].

\section{Chromophobe Renal Cell Carcinoma (chRCC)}

Chromophobe RCC, arising from the intercalated cells of the renal collecting ducts, represents 5\% of RCC cases. Histologically, chRCC can be grouped into the classic, eosinophilic, or mixed variants. Chromophobe RCC cells are large and polygonal with distinct cell borders and irregular, wrinkled nuclei. The classic variant has pale, finely granular cytoplasm while the eosinophilic variant has granular eosinophilic cytoplasm [201]. Clinical outcome is similar for the different variants [233]. Compared to other RCC subtypes, chRCC has a more positive clinical outcome as it is less likely to metastasize $[233,234]$. Metastasis at presentation is approximately 2.5$2.8 \%$ and disease progression after surgical resection occurs in $4.1-16.3 \%$ of chRCC patients $[233,235]$.

4.1. Birt-Hogg-Dubé (BHD) Gene. Hereditary chRCC is found in individuals with Birt-Hogg-Dubé syndrome (BHD). $\mathrm{BHD}$ is an autosomal dominant disorder characterised by benign skin lesions (fibrofolliculomas, trichodiscomas, and acrochordons), renal tumours, pulmonary cysts, and spontaneous pneumothorax. Renal tumours of different histologies such as ccRCC, pRCC, chRCC, and oncocytoma have been reported in BHD sufferers with chRCC and oncocytomas being the predominant types [204]. Germline mutation of the BHD or folliculin (FLCN) gene was discovered and mapped to chromosome $17 \mathrm{p} 11.2$ in families with BHD syndrome $[205,236]$. LOH, frameshift, or missense mutations inactivate the BHD gene, decreasing BHD mRNA levels and folliculin protein expression $[237,238]$. The function of the folliculin protein has not been completely elucidated but studies have shown that folliculin plays a role in mTOR complex 1 (TORC1) regulation [239, 240]. Kidney specific BHD knockout mice developed polycystic kidneys with upregulation of the Akt-mTOR signalling pathway, providing a link between BHD loss and renal oncogenesis [239, 240]. Unlike the VHL gene in ccRCC, $B H D$ mutation is rarely reported in sporadic renal tumours; hence the role of folliculin in sporadic RCC is unclear [241, 242]. However, Gad et al. reported BHD mutations in $10.9 \%$ of chRCC and $5.6 \%$ of oncocytomas from their case series of sporadic renal tumours [191].

4.2. Other Genetic Aberrations. Common genetic alterations found in sporadic chRCC are the LOH at chromosomes 1, 2, 6, $10,13,17$, and $21[187,188,243,244]$. There is no difference in chromosomal loss pattern between eosinophilic and classic variants of chRCC [189]. One frequently mutated candidate gene identified in sporadic chRCC is TP53 at 17p13.1 [191-193]. The TP53 TSG, which is commonly implicated in cancers, regulates cell cycle arrest, apoptosis, and cell differentiation, preventing impaired DNA from being passed on to the daughter cells [245]. Davis et al. identified mutations of PTEN in chRCC but an earlier study by Sükösd et al. found no PTEN mutation in chRCC $[192,246]$. Currently, no other candidate genes have been confirmed yet. Information on the prognostic value of genetic alterations in chRCC is scarce, possibly because of the low metastasis rate and good prognosis in chRCC. Gains of chromosomes 1-4, 6-12, 14, 15 , and 17 were associated with sarcomatoid transformation in chRCC but there was no relation between chromosome change and the Paner grading system $[61,190]$. This grading system, proposed by Paner et al., provides superior prognostic value in chRCC, compared to the Fuhrman grading system commonly used for ccRCC and pRCC [247].

\section{Differential Diagnosis}

Renal Oncocytoma. Chromophobe RCC and RO pose a diagnostic challenge as both tumours have morphological overlaps. Correct diagnosis is important because RO is largely benign while chRCC is malignant. Losses of chromosomes 2, $6,10,13,17$, and 21 , found in up to $93 \%$ of chRCCs, are not features of ROs and could be used to differentiate the two tumour types [243, 244, 248].

\section{Renal Oncocytoma (RO)}

Renal oncocytomas are benign neoplasms accounting for 3$7 \%$ of renal neoplasms. Originating from the collecting ducts, $\mathrm{RO}$ cells are arranged in a nested, tubular, or trabecular architecture with abundance of granular eosinophilic cytoplasm 
and round uniform nuclei [4]. To date, there has only been one histologically confirmed case of metastatic RO [249].

5.1. Genetic Aberrations. Similar to chRCC, BHD syndrome predisposes affected individuals to develop RO, but BHD mutation is seldom found in sporadic cases [241]. Other genetic alterations characteristic of ROs are losses at chromosomes 1, 14, and Y, as well as chromosome rearrangement at 11q13 [194, 196, 197, 244, 250]. Rearrangement of cyclin D1 (CCND1) gene has been linked to the translocation at $11 q 13[198,250]$. ROs with rearrangement at 11q13 have been reported along with overexpression of cyclin D1, the protein product of CCDN1 gene [198, 250]. Cyclin D1 is involved in the regulation of cell cycle in the G1-S phase and is found to be overexpressed in a few tumours such as Bcell lymphoma, breast cancer, and squamous cell carcinoma [251]. Dysregulation of cyclin D1 may contribute to the overproliferation of cells leading to RO formation.

\section{Differential Diagnosis}

Chromophobe RCC. As illustrated previously, losses of chromosomes 2, 6, 10, 13, 17, and 21 in chRCC distinguishe RO from chRCC. Both RO and chRCC contain loss of chromosome 1. It was proposed that chromosome 1 loss may represent a common early event in the tumourigenesis of both RO and chRCC [197, 248]. Additional losses of chromosomes $2,6,10,13,17$, and 21 in RO may lead to malignant transformation to chRCC [197, 248, 252].

\section{Collecting Duct Renal Cell Carcinoma (CDRCC)}

Collecting duct RCC is an uncommon histological subtype, accounting for $0.4-1.8 \%$ of all RCCs [253]. CDRCC cells have a tubulopapillary or hobnail structure, with eosinophilic cytoplasm and large nuclei. CDRCC is clinically aggressive with a higher metastatic rate and poorer prognosis compared to other RCC subtypes [253]. Patients are often diagnosed at an advanced stage, including $32-45 \%$ with distant metastasis and $42-44 \%$ with positive lymph nodes $[253,254]$.

6.1. Genetic Aberrations. A cytogenetics study found monosomies 1, 6, 14, 15, and 22 in three CDRCC tumours [202]. Another recent study in 29 CDRCC tumours reported genetic losses at $8 p, 16 p, 1 p$, and $9 p$ and gains in 13q [201]. Loss of chromosome 3 is rarely reported in CDRCC whereas frequent loss of chromosome 1 is similarly seen in RO and chRCC, both originating from the renal collecting duct [255]. Hence, loss of chromosome 1 might be more characteristic of renal tumours from the collecting duct whereas chromosome $3 \mathrm{p}$ loss is more typical of renal tumours from the proximal tubule [256]. Steiner et al. detected a region of genetic loss at 1q32.132.2 in $69 \%$ of CDRCC but no TSG has been identified yet [256].

Due to the rarity of CDRCC, knowledge on genetic aberrations and the role they play in pathogenesis of the tumour is lacking. A better understanding of the contribution of genetic alterations in CDRCC would be interesting because of the aggressive behaviour of the disease.

\section{Differential Diagnosis}

(i) Upper Urinary Tract Urothelial Carcinoma. Upper urinary tract urothelial carcinoma (UUTUC) and CDRCC display some similarities in histology and immunoreactivity and hence may present some difficulties in diagnosis [257]. A cytogenetic comparison of UUTUC and CDRCC showed distinct genetic alterations in the two tumour types [201]. CDC showed frequent losses at $8 \mathrm{p}, 16 \mathrm{p}, 1 \mathrm{p}$, and $9 \mathrm{p}$ and gains at $13 \mathrm{q}$ while UUTUC showed losses at 9q, 13q, and 8q and gains at $8 \mathrm{p}$ [201].

(ii) Renal Medullary Carcinoma. Renal medullary carcinoma (RMC) is a rare, highly aggressive form of kidney cancer with predominance in individuals with sickle cell trait. Renal medullary carcinoma and CDRCC are both aggressive with some similarities in morphology and immunoreactivity [258]. Swartz et al. analysed 9 RMC tumours for genetic aberrations but found only loss of chromosome 22 in one case [259]. The lack of genetic losses or gains was surprising given that RMCs are aggressive and are closely associated with sickle cell trait [259]. Gatalica et al. evaluated 3 patients with RMC for chromosomal abnormalities and compared their results with findings of other publications on RMC and CDRCC cytogenetics [260]. They concluded that no consistent chromosomal abnormalities were observed in RMCs or CDRCC [260]. However, limited studies due to the rarity of both tumour types may have contributed to these inconsistent findings.

(iii) Tubulocystic Renal Cell Carcinoma. Tubulocystic RCCs are characterised by multiple tubules and cysts with bubblewrap appearance, eosinophilic cytoplasm, and presence of hobnail cells [261]. It was originally thought to originate from the collecting duct and was classified as low grade CDRCC due to its indolent clinical behaviour [262]. Recent analyses have suggested that tubulocystic RCC might be of proximal tubule origin from its immunostaining profile and ultrastructural features ( $\operatorname{Pax} 2$ positivity and presence of short microvilli with brush border structure) [261, 263]. Zhou et al. and Al-Hussain et al. reported either gains of chromosomes 7 or 17 and loss of chromosome $\mathrm{Y}$ in their case series of tubulocystic RCC tumours, indicating similarities to pRCC $[263,264]$. The tumours that they analysed consisted of areas with coexisting pRCC or CDRCC morphologies [263, 264]. However, another case series by Amin et al. found none of these chromosomal anomalies typical of pRCC [261]. A possible reason for this discrepancy could be that the tumours analysed by Amin et al. were purely tubulocystic RCC without coexisting pRCC morphology. More studies are required for a clearer understanding of genetic changes in these tumours.

\section{Conclusions}

Each RCC subtype has a distinctive pattern of genetic aberrations, although there are some overlaps in chromosomal 
and genetic changes. These genetic changes may play an important role in tumourigenesis and affect the progression or prognosis of the tumour. However, most genetic studies were concentrated on ccRCC and pRCC as they are two most common forms of RCC. More studies on other RCC subtypes are needed to identify the specific genetic changes which may be involved in tumourigenesis. Recent genetic studies have employed gene sequencing or gene expression profiling for discovery of novel gene mutations which could identify possible differentially expressed proteins in RCC subtypes. These proteins can be part of an immunoreactivity panel for diagnosis of RCC subtypes. Hence, detection of genetic or chromosomal changes could be a useful diagnostic or prognostic tool as adjunct to conventional immunohistochemistry and histology. Identification of frequently mutated genes and affected signalling pathways also allows for development of new therapeutic targets or personalised targeted therapy for better management of advanced RCC.

\section{Conflict of Interests}

The authors declare that there is no conflict of interests regarding the publication of this paper.

\section{Acknowledgment}

This review paper was supported by University Malaya Research Fund Assistance BK024-2013.

\section{References}

[1] M. Sun, R. Thuret, F. Abdollah et al., "Age-adjusted incidence, mortality, and survival rates of stage-specific renal cell carcinoma in North America: a trend analysis," European Urology, vol. 59, no. 1, pp. 135-141, 2011.

[2] N. Y. Yap, K. L. Ng, T. A. Ong et al., "Clinical prognostic factors and survival outcome in renal cell carcinoma patientsa Malaysian single centre perspective," Asian Pacific Journal of Cancer Prevention, vol. 14, no. 12, pp. 7497-7500, 2013.

[3] A. Znaor, J. Lortet-Tieulent, A. Jemal, and F. Bray, "International variations and trends in testicular cancer incidence and mortality," European Urology, vol. 65, no. 6, pp. 1095-1106, 2014.

[4] K. L. Ng, R. Rajandram, C. Morais et al., "Differentiation of oncocytoma from chromophobe renal cell carcinoma (RCC): can novel molecular biomarkers help solve an old problem?" Journal of Clinical Pathology, vol. 67, no. 2, pp. 97-104, 2014.

[5] D. Hanahan and R. A. Weinberg, "Hallmarks of cancer: the next generation," Cell, vol. 144, no. 5, pp. 646-674, 2011.

[6] B. Vogelstein and K. W. Kinzler, "Cancer genes and the pathways they control," Nature Medicine, vol. 10, no. 8, pp. 789-799, 2004.

[7] T. Sjöblom, "Systematic analyses of the cancer genome: lessons learned from sequencing most of the annotated human proteincoding genes," Current Opinion in Oncology, vol. 20, no. 1, pp. 66-71, 2008.

[8] A. Salvi, E. Marchina, A. Benetti, P. Grigolato, G. de Petro, and S. Barlati, "Germline and somatic c-met mutations in multifocal/bilateral and sporadic papillary renal carcinomas of selected patients," International Journal of Oncology, vol. 33, no. 2, pp. 271-276, 2008.
[9] S. Richard, R. Lidereau, and S. Giraud, "The growing family of hereditary renal cell carcinoma," Nephrology Dialysis Transplantation, vol. 19, no. 12, pp. 2954-2958, 2004.

[10] C. S. Ng, C. G. Wood, P. M. Silverman, N. M. Tannir, P. Tamboli, and C. M. Sandler, "Renal cell carcinoma: diagnosis, staging, and surveillance," American Journal of Roentgenology, vol. 191, no. 4, pp. 1220-1232, 2008.

[11] F. Algaba, H. Akaza, A. López-Beltrán et al., "Current pathology keys of renal cell carcinoma," European Urology, vol. 60, no. 4, pp. 634-643, 2011.

[12] B. C. Leibovich, C. M. Lohse, P. L. Crispen et al., "Histological subtype is an independent predictor of outcome for patients with renal cell carcinoma," Journal of Urology, vol. 183, no. 4, pp. 1309-1316, 2010.

[13] J.-J. Patard, E. Leray, N. Rioux-Leclercq et al., "Prognostic value of histologic subtypes in renal cell carcinoma: a multicenter experience," Journal of Clinical Oncology, vol. 23, no. 12, pp. 2763-2771, 2005.

[14] V. Ficarra, G. Martignoni, A. Galfano et al., "Prognostic role of the histologic subtypes of renal cell carcinoma after slide revision," European Urology, vol. 50, no. 4, pp. 786-794, 2006.

[15] K. Foster, P. A. Crossey, P. Cairns et al., "Molecular genetic investigation of sporadic renal cell carcinoma: analysis of allele loss on chromosomes 3p, 5q, 11p, 17 and 22," British Journal of Cancer, vol. 69, no. 2, pp. 230-234, 1994.

[16] J. C. Strefford, I. Stasevich, T. M. Lane, Y.-J. Lu, T. Oliver, and B. D. Young, "A combination of molecular cytogenetic analyses reveals complex genetic alterations in conventional renal cell carcinoma," Cancer Genetics and Cytogenetics, vol. 159, no. 1, pp. $1-9,2005$.

[17] M. I. Toma, M. Grosser, A. Herr et al., "Loss of heterozygosity and copy number abnormality in clear cell renal cell carcinoma discovered by high-density affymetrix $10 \mathrm{~K}$ single nucleotide polymorphism mapping array," Neoplasia, vol. 10, no. 7, pp. 634642, 2008.

[18] F. Latif, K. Tory, J. Gnarra et al., "Identification of the von Hippel-Lindau disease tumor suppressor gene," Science, vol. 260, no. 5112, pp. 1317-1320, 1993.

[19] S. Richard, B. Gardie, S. Couvé, and S. Gad, "Von HippelLindau: how a rare disease illuminates cancer biology," Seminars in Cancer Biology, vol. 23, no. 1, pp. 26-37, 2013.

[20] C. A. Friedrich, "Von Hippel-Lindau syndrome. A pleomorphic condition," Cancer, vol. 86, no. 11, pp. 2478-2482, 1999.

[21] H. P. H. Neumann, B. U. Bender, D. P. Berger et al., "Prevalence, morphology and biology of renal cell carcinoma in von HippelLindau disease compared to sporadic renal cell carcinoma," Journal of Urology, vol. 160, no. 4, pp. 1248-1254, 1998.

[22] M. Krieg, R. Haas, H. Brauch, T. Acker, I. Flamme, and K. H. Plate, "Up-regulation of hypoxia-inducible factors HIF- $1 \alpha$ and HIF- $2 \alpha$ under normoxic conditions in renal carcinoma cells by von Hippel-Lindau tumor suppressor gene loss of function," Oncogene, vol. 19, no. 48, pp. 5435-5443, 2000.

[23] P. H. Maxwell, M. S. Wlesener, G. W. Chang et al., "The tumour suppressor protein VHL targets hypoxia-inducible factors for oxygen-dependent proteolysis," Nature, vol. 399, no. 6733, pp. 271-275, 1999.

[24] M. E. Cockman, N. Masson, D. R. Mole et al., "Hypoxia inducible factor-alpha binding and ubiquitylation by the von Hippel-Lindau tumour suppressor protein," The Journal of Biological Chemistry, vol. 275, no. 33, pp. 25733-25741, 2000. 
[25] J. Bellmunt, "Current treatment in advanced renal cell carcinoma (RCC): impact of targeted therapies in the management of RCC," European Urology Supplements, vol. 6, no. 7, pp. 484491, 2007.

[26] P. Staller, J. Sulitkova, J. Lisztwan, H. Moch, E. J. Oakeley, and W. Krek, "Chemokine receptor CXCR4 downregulated by von Hippel-Lindau tumour suppressor pVHL," Nature, vol. 425, no. 6955, pp. 307-311, 2003.

[27] N. de Paulsen, A. Brychzy, M. C. Fournier et al., "Role of transforming growth factor- $\alpha$ in von Hippel-Lindau (VHL) $)^{-/-}$clear cell renal carcinoma cell proliferation: a possible mechanism coupling VHL tumor suppressor inactivation and tumorigenesis," Proceedings of the National Academy of Sciences of the United States of America, vol. 98, no. 4, pp. 1387-1392, 2001.

[28] W. Y. Kim and W. G. Kaelin, "Role of VHL gene mutation in human cancer," Journal of Clinical Oncology, vol. 22, no. 24, pp. 4991-5004, 2004.

[29] A. G. Knudson Jr., L. C. Strong, and D. E. Anderson, "Heredity and cancer in man," Progress in Medical Genetics, vol. 9, pp. 113$158,1973$.

[30] K. Kondo, M. Yao, M. Yoshida et al., "Comprehensive mutational analysis of the VHL gene in sporadic renal cell carcinoma: relationship to clinicopathological parameters," Genes Chromosomes and Cancer, vol. 34, no. 1, pp. 58-68, 2002.

[31] K. P. van Houwelingen, B. A. C. van Dijk, C. A. Hulsbergen-van de Kaa et al., "Prevalence of von Hippel-Lindau gene mutations in sporadic renal cell carcinoma: results from The Netherlands cohort study," BMC Cancer, vol. 5, article 57, 2005.

[32] C. Gallou, D. Joly, A. Méjean et al., "Mutations of the VHL gene in sporadic renal cell carcinoma: definition of a risk factor for VHL patients to develop an RCC," Human Mutation, vol. 13, no. 6, pp. 464-475, 1999.

[33] H. Moch, P. Schraml, L. Bubendorf et al., "Intratumoral heterogeneity of von Hippel-Lindau gene deletions in renal cell carcinoma detected by fluorescence in situ hybridization," Cancer Research, vol. 58, no. 11, pp. 2304-2309, 1998.

[34] S. C. Clifford, A. H. Prowse, N. A. Affara, C. H. C. M. Buys, and E. R. Maher, "Inactivation of the von Hippel-Lindau (VHL) tumour suppressor gene and allelic losses at chromosome arm $3 p$ in primary renal cell carcinoma: evidence for a VHLindependent pathway in clear cell renal tumourigenesis," Genes Chromosomes and Cancer, vol. 22, no. 3, pp. 200-209, 1998.

[35] P. Schraml, K. Struckmann, F. Hatz et al., "VHL mutations and their correlation with tumour cell proliferation, microvessel density, and patient prognosis in clear cell renal cell carcinoma," The Journal of Pathology, vol. 196, no. 2, pp. 186-193, 2002.

[36] K. M. Smits, L. J. Schouten, B. A. C. van Dijk et al., "Genetic and epigenetic alterations in the von Hippel-Lindau gene: the influence on renal cancer prognosis," Clinical Cancer Research, vol. 14, no. 3, pp. 782-787, 2008.

[37] M. R. Alves, F. C. Carneiro, A. M. Lavorato-Rocha et al., "Mutational status of VHL gene and its clinical importance in renal clear cell carcinoma," Virchows Archiv, vol. 465, no. 3, pp. 321-330, 2014.

[38] M. M. Baldewijns, I. J. H. van Vlodrop, K. M. Smits et al., "Different angiogenic potential in low and high grade sporadic clear cell renal cell carcinoma is not related to alterations in the von Hippel-Lindau gene," Cellular Oncology, vol. 31, no. 5, pp. 371-382, 2009.

[39] H. Brauch, G. Weirich, J. Brieger et al., "VHL alterations in human clear cell renal cell carcinoma: association with advanced tumor stage and a novel hot spot mutation," Cancer Research, vol. 60, no. 7, pp. 1942-1948, 2000.

[40] A. C. Young, R. A. Craven, D. Cohen et al., "Analysis of VHL gene alterations and their relationship to clinical parameters in sporadic conventional renal cell carcinoma," Clinical Cancer Research, vol. 15, no. 24, pp. 7582-7592, 2009.

[41] A. S. Parker, J. C. Cheville, C. M. Lohse, T. Igel, B. C. Leibovich, and M. L. Blute, "Loss of expression of von Hippel-Lindau tumor suppressor protein associated with improved survival in patients with early-stage clear cell renal cell carcinoma," Urology, vol. 65, no. 6, pp. 1090-1095, 2005.

[42] J.-J. Patard, P. Fergelot, P. I. Karakiewicz et al., "Low CAIX expression and absence of VHL gene mutation are associated with tumor aggressiveness and poor survival of clear cell renal cell carcinoma," International Journal of Cancer, vol. 123, no. 2, pp. 395-400, 2008.

[43] M. Yao, M. Yoshida, T. Kishida et al., "VHL tumor suppressor gene alterations associated with good prognosis in sporadic clear-cell renal carcinoma," Journal of the National Cancer Institute, vol. 94, no. 20, pp. 1569-1575, 2002.

[44] J.-J. Patard, N. Rioux-Leclercq, D. Masson et al., "Absence of VHL gene alteration and high VEGF expression are associated with tumour aggressiveness and poor survival of renal-cell carcinoma," British Journal of Cancer, vol. 101, no. 8, pp. 14171424,2009

[45] M. N. Fishman, "Targeted therapy of kidney cancer: keeping the art around the algorithms," Cancer Control, vol. 20, no. 3, pp. 222-232, 2013.

[46] A. V. Soerensen, F. Donskov, G. G. Hermann et al., "Improved overall survival after implementation of targeted therapy for patients with metastatic renal cell carcinoma: Results from the Danish Renal Cancer Group (DARENCA) study-2," European Journal of Cancer, vol. 50, no. 3, pp. 553-562, 2014.

[47] R. A. Nelson, N. Vogelzang, and S. K. Pal, "A gap in diseasespecific survival between younger and older adults with de novo metastatic renal cell carcinoma: results of a seer database analysis," Clinical Genitourinary Cancer, vol. 11, no. 3, pp. $303-$ 310, 2013.

[48] A. J. Cohen, F. P. Li, S. Berg et al., "Hereditary renal-cell carcinoma associated with a chromosomal translocation," The New England Journal of Medicine, vol. 301, no. 11, pp. 592-595, 1979.

[49] D. Bodmer, M. Eleveld, M. Ligtenberg et al., "Cytogenetic and molecular analysis of early stage renal cell carcinomas in a family with a translocation (2;3)(q35;q21)," Cancer Genetics and Cytogenetics, vol. 134, no. 1, pp. 6-12, 2002.

[50] J. Chen, W.-O. Lui, M. D. Vos et al., "The $t(1 ; 3)$ breakpointspanning genes LSAMP and NORE1 are involved in clear cell renal cell carcinomas," Cancer Cell, vol. 4, no. 5, pp. 405-413, 2003.

[51] J. Podolski, T. Byrski, S. Zajaczek et al., "Characterization of a familial RCC-associated $\mathrm{t}(2 ; 3)(\mathrm{q} 33 ; \mathrm{q} 21)$ chromosome translocation," Journal of Human Genetics, vol. 46, no. 12, pp. 685-693, 2001.

[52] B. Meléndez, S. Rodríguez-Perales, B. Martínez-Delgado et al., "Molecular study of a new family with hereditary renal cell carcinoma and a translocation $\mathrm{t}(3 ; 8)(\mathrm{p} 13 ; \mathrm{q} 24.1)$," Human Genetics, vol. 112, no. 2, pp. 178-185, 2003.

[53] M. J. Eleveld, D. Bodmer, G. Merkx et al., "Molecular analysis of a familial case of renal cell cancer and a $\mathrm{t}(3 ; 6)$ (q12;q15)," Genes Chromosomes and Cancer, vol. 31, no. 1, pp. 23-32, 2001. 
[54] A. C. M. Bonné, D. Bodmer, E. F. P. M. Shoenmakers, C. M. van Ravenswaaij, N. Hoogerbrugge, and A. G. van Kessel, "Chromosome 3 translocations and familial renal cell cancer," Current Molecular Medicine, vol. 4, no. 8, pp. 849-854, 2004.

[55] G. Kovacs, P. Brusa, and W. De Riese, "Tissue-specific expression of a constitutional 3;6 translocation: development of multiple bilateral renal-cell carcinomas," International Journal of Cancer, vol. 43, no. 3, pp. 422-427, 1989.

[56] R. P. Kuiper, L. Vreede, R. Venkatachalam et al., "The tumour suppressor gene FBXW7 is disrupted by a constitutional $t(3$; 4)(q21; q31) in a patient with renal cell cancer," Cancer Genetics and Cytogenetics, vol. 195, no. 2, pp. 105-111, 2009.

[57] A. G. van Kessel Geurts, H. Wijnhoven, D. Bodmer et al., "Renal cell cancer: chromosome 3 translocations as risk factors," Journal of the National Cancer Institute, vol. 91, no. 13, pp. 11591160, 1999.

[58] R. E. Foster, M. Abdulrahman, M. R. Morris et al., "Characterization of a 3;6 translocation associated with renal cell carcinoma," Genes Chromosomes and Cancer, vol. 46, no. 4, pp. 311-317, 2007.

[59] D. Bodmer, M. J. Eleveld, M. J. L. Ligtenberg et al., "An alternative route for multistep tumorigenesis in a novel case of hereditary renal cell cancer and a $\mathrm{t}(2 ; 3)(\mathrm{q} 35 ; \mathrm{q} 21)$ chromosome translocation," The American Journal of Human Genetics, vol. 62, no. 6, pp. 1475-1483, 1998.

[60] A. Martinez, P. Fullwood, K. Kondo et al., "Role of chromosome 3p12-p21 tumour suppressor genes in clear cell renal cell carcinoma: analysis of VHL dependent and VHL independent pathways of tumorigenesis," The Journal of Clinical PathologyMolecular Pathology, vol. 53, no. 3, pp. 137-144, 2000.

[61] F. P. Li, H.-J. H. Decker, B. Zbar et al., "Clinical and genetic studies of renal cell carcinomas in a family with a constitutional chromosome 3;8 translocation. Genetics of familial renal carcinoma," Annals of Internal Medicine, vol. 118, no. 2, pp. 106-111, 1993.

[62] T. Druck, K. Kastury, P. Hadaczek et al., "Loss of heterozygosity at the familial RCC $\mathrm{t}(3 ; 8)$ locus in most clear cell renal carcinomas," Cancer Research, vol. 55, no. 22, pp. 5348-5353, 1995.

[63] F. Sükösd, N. Kuroda, T. Beothe, A. P. Kaur, and G. Kovacs, "Deletion of chromosome 3p14.2-p25 involving the VHL and FHIT genes in conventional renal cell carcinoma," Cancer Research, vol. 63, no. 2, pp. 455-457, 2003.

[64] R. B. Singh and P. S. Amare Kadam, "Investigation of tumor suppressor genes apart from $V H L$ on $3 p$ by deletion mapping in sporadic clear cell renal cell carcinoma (cRCC)," Urologic Oncology, vol. 31, no. 7, pp. 1333-1342, 2013.

[65] G. Toledo, J. J. Sola, M. D. Lozano, E. Soria, and J. Pardo, "Loss of FHIT protein expression is related to high proliferation, low apoptosis and worse prognosis in non-small-cell lung cancer," Modern Pathology, vol. 17, no. 4, pp. 440-448, 2004.

[66] A. Vecchione, C. Sevignani, E. Giarnieri et al., "Inactivation of the FHIT gene favors bladder cancer development," Clinical Cancer Research, vol. 10, no. 22, pp. 7607-7612, 2004.

[67] Q. Yang, M. Nakamura, Y. Nakamura et al., "Two-hit inactivation of FHIT by loss of heterozygosity and hypermethylation in breast cancer," Clinical Cancer Research, vol. 8, no. 9, pp. 28902893, 2002.

[68] C. Huiping, S. Kristjansdottir, J. T. Bergthorsson et al., "High frequency of LOH, MSI and abnormal expression of FHIT in gastric cancer," European Journal of Cancer, vol. 38, no. 5, pp. 728-735, 2002.
[69] D. Butler, C. Collins, M. Mabruk, C. B. Walsh, M. B. Leader, and E. W. Kay, "Deletion of the FHIT gene in neoplastic and invasive cervical lesions is related to high-risk HPV infection but is independent of histopathological features," Journal of Pathology, vol. 192, no. 4, pp. 502-510, 2000.

[70] V. Shridhar, L. Wang, R. Rosati et al., "Frequent breakpoints in the region surrounding FRA3B in sporadic renal cell carcinomas," Oncogene, vol. 14, no. 11, pp. 1269-1277, 1997.

[71] J. R. Karras, C. A. Paisie, and K. Huebner, "Replicative stress and the FHIT gene: roles in tumor suppression, genome stability and prevention of carcinogenesis," Cancers, vol. 6, no. 2, pp. 12081219, 2014.

[72] P. Hadaczek, A. L. Kovatich, J. Gronwald, J. Lubinski, K. Huebner, and P. A. Mccue, "Loss or reduction of Fhit expression in renal neoplasias: correlation with histogenic class," Human Pathology, vol. 30, no. 11, pp. 1276-1283, 1999.

[73] U. Ramp, E. Caliskan, T. Ebert et al., "FHIT expression in clear cell renal carcinomas: versatility of protein levels and correlation with survival," Journal of Pathology, vol. 196, no. 4, pp. 430-436, 2002.

[74] E. J. Eyzaguirre, M. Miettinen, B. A. Norris, and Z. Gatalica, "Different immunohistochemical patterns of Fhit protein expression in renal neoplasms," Modern Pathology, vol. 12, no. 10, pp. 979-983, 1999.

[75] N. Zanesi, V. Fidanza, L. Y. Fong et al., "The tumor spectrum in FHIT-deficient mice," Proceedings of the National Academy of Sciences of the United States of America, vol. 98, no. 18, pp. 10250-10255, 2001.

[76] T. Fujishita, Y. Doi, M. Sonoshita et al., "Development of spontaneous tumours and intestinal lesions in Fhit gene knockout mice," British Journal of Cancer, vol. 91, no. 8, pp. 1571-1574, 2004.

[77] P. Hadaczek, Z. Siprashvili, M. Markiewski et al., "Absence or reduction of FHIT expression in most clear cell renal carcinomas," Cancer Research, vol. 58, no. 14, pp. 2946-2951, 1998.

[78] M. Velickovic, B. Delahunt, and S. K. G. Grebe, "Loss of heterozygosity at 3p14.2 in clear cell renal cell carcinoma is an early event and is highly localized to the FHIT gene locus," Cancer Research, vol. 59, no. 6, pp. 1323-1326, 1999.

[79] H. Donninger, J. A. Clark, M. K. Monaghan, M. L. Schmidt, M. Vos, and G. J. Clark, "Cell cycle restriction is more important than apoptosis induction for RASSF1A protein tumor suppression," The Journal of Biological Chemistry, vol. 289, no. 45, pp. 31287-31295, 2014.

[80] L. Shivakumar, J. Minna, T. Sakamaki, R. Pestell, and M. A. White, "The RASSF1A tumor suppressor blocks cell cycle progression and inhibits cyclin D1 accumulation," Molecular and Cellular Biology, vol. 22, no. 12, pp. 4309-4318, 2002.

[81] J.-H. Yoon, R. Dammann, and G. P. Pfeifer, "Hypermethylation of the CpG island of the RASSF1A gene in ovarian and renal cell carcinomas," International Journal of Cancer, vol. 94, no. 2, pp. 212-217, 2001.

[82] W. Yeo, W. L. Wong, N. Wong, B. K. Law, G. M. Tse, and S. Zhong, "High frequency of promoter hypermethylation of RASSF1A in tumorous and non-tumourous tissue of breast cancer," Pathology, vol. 37, no. 2, pp. 125-130, 2005.

[83] N. Yanagawa, G. Tamura, H. Oizumi et al., "Promoter hypermethylation of RASSF1A and RUNX3 genes as an independent prognostic prediction marker in surgically resected non-small cell lung cancers," Lung Cancer, vol. 58, no. 1, pp. 131-138, 2007. 
[84] I. Peters, K. Rehmet, N. Wilke et al., "RASSF1A promoter methylation and expression analysis in normal and neoplastic kidney indicates a role in early tumorigenesis," Molecular Cancer, vol. 6, article 49, 2007.

[85] Y. Kawai, S. Sakano, Y. Suehiro et al., "Methylation level of the RASSF1A promoter is an independent prognostic factor for clear-cell renal cell carcinoma," Annals of Oncology, vol. 21, no. 8, pp. 1612-1617, 2010.

[86] V. I. Loginov, D. S. Khodyrev, I. V. Pronina et al., "Methylation of promoter region of RASSF1A gene and frequencies of allelic imbalances in chromosome 3 critical regions are correlated with progression of clear cell renal cell carcinoma," Molekuliarnaia Biologiia, vol. 43, no. 3, pp. 429-438, 2009.

[87] H. Tezval, A. S. Merseburger, I. Matuschek, S. Machtens, M. A. Kuczyk, and J. Serth, "RASSF1A protein expression and correlation with clinicopathological parameters in renal cell carcinoma," BMC Urology, vol. 8, article 12, 2008.

[88] C. Morrissey, A. Martinez, M. Zatyka et al., "Epigenetic inactivation of the RASSF1A 3p21.3 tumor suppressor gene in both clear cell and papillary renal cell carcinoma," Cancer Research, vol. 61, no. 19, pp. 7277-7281, 2001.

[89] G. Duns, R. M. W. Hofstra, J. G. Sietzema et al., "Targeted exome sequencing in clear cell renal cell carcinoma tumors suggests aberrant chromatin regulation as a crucial step in ccRCC development," Human Mutation, vol. 33, no. 7, pp. 10591062, 2012.

[90] I. Varela, P. Tarpey, K. Raine et al., "Exome sequencing identifies frequent mutation of the SWI/SNF complex gene PBRM1 in renal carcinoma," Nature, vol. 469, no. 7331, pp. 539-542, 2011.

[91] S. Peña-Llopis, S. Vega-Rubín-De-Celis, A. Liao et al., "BAP1 loss defines a new class of renal cell carcinoma," Nature Genetics, vol. 44, no. 7, pp. 751-759, 2012.

[92] A. A. Hakimi, Y.-B. Chen, J. Wren et al., "Clinical and pathologic impact of select chromatin-modulating tumor suppressors in clear cell renal cell carcinoma," European Urology, vol. 63, no. 5, pp. 848-854, 2013.

[93] Z. Lichner, A. Scorilas, N. M. A. White et al., "The chromatin remodeling gene ARIDIA is a new prognostic marker in clear cell renal cell carcinoma," The American Journal of Pathology, vol. 182, no. 4, pp. 1163-1170, 2013.

[94] L. Liao, J. R. Testa, and H. Yang, "The roles of chromatinremodelers and epigenetic modifiers in kidney cancer," Cancer Genetics, 2015.

[95] M. Gerlinger, S. Horswell, J. Larkin et al., "Genomic architecture and evolution of clear cell renal cell carcinomas defined by multiregion sequencing," Nature Genetics, vol. 46, no. 3, pp. 225-233, 2014.

[96] A. Sankin, A. A. Hakimi, N. Mikkilineni et al., "The impact of genetic heterogeneity on biomarker development in kidney cancer assessed by multiregional sampling," Cancer Medicine, vol. 3, no. 6, pp. 1485-1492, 2014.

[97] P. R. Benusiglio, S. Couve, B. Gilbert-Dussardier et al., "A germline mutation in PBRM1 predisposes to renal cell carcinoma," Journal of Medical Genetics, vol. 52, no. 6, pp. 426-430, 2015.

[98] M. N. Farley, L. S. Schmidt, J. L. Mester et al., "A novel germline mutation in BAP1 predisposes to familial clear-cell renal cell carcinoma," Molecular Cancer Research, vol. 11, no. 9, pp. 10611071, 2013.

[99] T. Popova, L. Hebert, V. Jacquemin et al., "Germline BAP1 mutations predispose to renal cell carcinomas," American Journal of Human Genetics, vol. 92, no. 6, pp. 974-980, 2013.
[100] J. Stein, M. Majores, M. Rohde et al., "KDM5C is overexpressed in prostate cancer and is a prognostic marker for prostatespecific antigen-relapse following radical prostatectomy," The American Journal of Pathology, vol. 184, no. 9, pp. 2430-2437, 2014.

[101] A. Mamo, L. Cavallone, S. Tuzmen et al., "An integrated genomic approach identifies ARID1A as a candidate tumorsuppressor gene in breast cancer," Oncogene, vol. 31, no. 16, pp. 2090-2100, 2012.

[102] W. Al Sarakbi, W. Sasi, W. G. Jiang, T. Roberts, R. F. Newbold, and K. Mokbel, "The mRNA expression of SETD2 in human breast cancer: correlation with clinico-pathological parameters," BMC Cancer, vol. 9, no. 1, article 290, 2009.

[103] R. Pawłowski, S. M. Mühl, T. Sulser, W. Krek, H. Moch, and P. Schraml, "Loss of PBRM1 expression is associated with renal cell carcinoma progression," International Journal of Cancer, vol. 132, no. 2, pp. E11-E17, 2013.

[104] W. H. da Costa, M. Rezende, F. C. Carneiro et al., "Polybromo-1 (PBRM1), a SWI/SNF complex subunit is a prognostic marker in clear cell renal cell carcinoma," BJU International, vol. 113, no. 5b, pp. E157-E163, 2014.

[105] A. A. Hakimi, I. Ostrovnaya, B. Reva et al., "Adverse outcomes in clear cell renal cell carcinoma with mutations of 3 p21 epigenetic regulators BAP1 and SETD2: A report by MSKCC and the KIRC TCGA research network," Clinical Cancer Research, vol. 19, no. 12, pp. 3259-3267, 2013.

[106] Y. Sato, T. Yoshizato, Y. Shiraishi et al., "Integrated molecular analysis of clear-cell renal cell carcinoma," Nature Genetics, vol. 45, no. 8, pp. 860-867, 2013.

[107] P. Kapur, A. Christie, J. D. Raman et al., "BAP1 immunohistochemistry predicts outcomes in a multi-institutional cohort with clear cell renal cell carcinoma," Journal of Urology, vol. 191, no. 3, pp. 603-610, 2014.

[108] L. Albiges, J. Guegan, A. Le Formal et al., "MET is a potential target across all papillary renal cell carcinomas: result from a large molecular study of pRCC with CGH array and matching gene expression array," Clinical Cancer Research, vol. 20, no. 13, pp. 3411-3421, 2014.

[109] L. Gossage, M. Murtaza, A. F. Slatter et al., "Clinical and pathological impact of VHL, PBRM1, BAP1, SETD2, KDM6A, and JARID1c in clear cell renal cell carcinoma," Genes Chromosomes and Cancer, vol. 53, no. 1, pp. 38-51, 2014.

[110] P. Kapur, S. Peña-Llopis, A. Christie et al., "Effects on survival of BAP1 and PBRM1 mutations in sporadic clear-cell renal-cell carcinoma: a retrospective analysis with independent validation," The Lancet Oncology, vol. 14, no. 2, pp. 159-167, 2013.

[111] J. H. Park, C. Lee, J. H. Suh, J. Y. Chae, H. W. Kim, and K. C. Moon, "Decreased ARID1A expression correlates with poor prognosis of clear cell renal cell carcinoma," Human Pathology, vol. 46, no. 3, pp. 454-460, 2015.

[112] K. Nagao, S. Yoshihiro, H. Matsuyama, S. Yamaguchi, K. Oba, and K. Naito, "Clinical significance of allelic loss of chromosome region 5 q22.3 approximately q23.2 in nonpapillary renal cell carcinoma," Cancer Genetics and Cytogenetics, vol. 136, no. 1, pp. 23-30, 2002.

[113] K. Nagao, S. Yamaguchi, H. Matsuyama et al., "Allelic loss of 3 p25 associated with alterations of 5 q22.3 q23.2 may affect the prognosis of conventional renal cell carcinoma," Cancer Genetics and Cytogenetics, vol. 160, no. 1, pp. 43-48, 2005.

[114] B. Gunawan, W. Huber, M. Holtrup et al., "Prognostic impacts of cytogenetic findings in clear cell renal cell carcinoma: gain of 
5q31-qter predicts a distinct clinical phenotype with favorable prognosis," Cancer Research, vol. 61, no. 21, pp. 7731-7738, 2001.

[115] J. C. Presti Jr., M. Wilhelm, V. Reuter, P. Russo, R. Motzer, and F. Waldman, "Allelic loss on chromosomes 8 and 9 correlates with clinical outcome in locally advanced clear cell carcinoma of the kidney," The Journal of Urology, vol. 167, no. 3, pp. 1464-1468, 2002.

[116] D. Schullerus, J. Herbers, J. Chudek, H. Kanamaru, and G. Kovacs, "Loss of heterozygosity at chromosomes 8p, 9p, and 14q is associated with stage and grade of non-papillary renal cell carcinomas," Journal of Pathology, vol. 183, no. 2, pp. 151-155, 1997.

[117] J. la Rochelle, T. Klatte, A. Dastane et al., "Chromosome 9p deletions identify an aggressive phenotype of clear cell renal cell carcinoma," Cancer, vol. 116, no. 20, pp. 4696-4702, 2010.

[118] B. Grady, R. Goharderakhshan, J. Chang et al., "Frequently deleted loci on chromosome 9 may harbor several tumor suppressor genes in human renal cell carcinoma," Journal of Urology, vol. 166, no. 3, pp. 1088-1092, 2001.

[119] P. Schraml, K. Struckmann, R. Bednar et al., "CDKN2A mutation analysis, protein expression, and deletion mapping of chromosome 9p conventional clear-cell renal carcinomas: evidence for a second tumor suppressor gene proximal to CDKN2A," American Journal of Pathology, vol. 158, no. 2, pp. 593-601, 2001.

[120] D. de Oliveira, M. F. Dall'Oglio, S. T. Reis et al., "Chromosome $9 \mathrm{p}$ deletions are an independent predictor of tumor progression following nephrectomy in patients with localized clear cell renal cell carcinoma," Urologic Oncology, vol. 32, no. 5, pp. 601-606, 2014.

[121] F. A. Monzon, K. Alvarez, L. Peterson et al., "Chromosome $14 \mathrm{q}$ loss defines a molecular subtype of clear-cell renal cell carcinoma associated with poor prognosis," Modern Pathology, vol. 24, no. 11, pp. 1470-1479, 2011.

[122] W. H. Liggett Jr. and D. Sidransky, "Role of the p16 tumour suppressor gene in cancer," Journal of Clinical Oncology, vol. 16, no. 3, pp. 1197-1206, 1998.

[123] Cancer Genome Atlas Research Network, "Comprehensive molecular characterization of clear cell renal cell carcinoma," Nature, vol. 499, no. 7456, pp. 43-49, 2013.

[124] H. Guo, P. German, S. Bai et al., "The PI3K/AKT pathway and renal cell carcinoma," Journal of Genetics and Genomics, 2015.

[125] R. Bhatnagar and B. A. Alexiev, "Renal-cell carcinomas in endstage kidneys: a clinicopathological study with emphasis on clear-cell papillary renal-cell carcinoma and acquired cystic kidney disease-associated carcinoma," International Journal of Surgical Pathology, vol. 20, no. 1, pp. 19-28, 2012.

[126] S. Gobbo, J. N. Eble, D. J. Grignon et al., "Clear cell papillary renal cell carcinoma: a distinct histopathologic and molecular genetic entity," American Journal of Surgical Pathology, vol. 32, no. 8, pp. 1239-1245, 2008.

[127] J. Adam, J. Couturier, V. Molinié, A. Vieillefond, and M. Sibony, "Clear-cell papillary renal cell carcinoma: 24 cases of a distinct low-grade renal tumour and a comparative genomic hybridization array study of seven cases," Histopathology, vol. 58, no. 7, pp. 1064-1071, 2011.

[128] H. Aydin, L. Chen, L. Cheng et al., "Clear cell tubulopapillary renal cell carcinoma: a study of 36 distinctive low-grade epithelial tumors of the kidney," American Journal of Surgical Pathology, vol. 34, no. 11, pp. 1608-1621, 2010.

[129] S. M. Rohan, Y. Xiao, Y. Liang et al., "Clear-cell papillary renal cell carcinoma: molecular and immunohistochemical analysis with emphasis on the von Hippel-Lindau gene and hypoxiainducible factor pathway-related proteins," Modern Pathology, vol. 24, no. 9, pp. 1207-1220, 2011.

[130] B. Delahunt and J. N. Eble, "Papillary renal cell carcinoma: a clinicopathologic and immunohistochemical study of 105 tumors," Modern Pathology, vol. 10, no. 6, pp. 537-544, 1997.

[131] G. Pignot, C. Elie, S. Conquy et al., "Survival analysis of 130 patients with papillary renal cell carcinoma: prognostic utility of type 1 and type 2 subclassification," Urology, vol. 69, no. 2, pp. 230-235, 2007.

[132] I. Balint, A. Szponar, A. Jauch, and G. Kovacs, “Trisomy 7 and 17 mark papillary renal cell tumours irrespectively of variation of the phenotype," Journal of Clinical Pathology, vol. 62, no. 10, pp. 892-895, 2009.

[133] P. S. Amare, C. Varghese, S. H. Bharde et al., "Proliferating cell nuclear antigen and epidermal growth factor receptor (EGFr) status in renal cell carcinoma patients with polysomy of chromosome 7," Cancer Genetics and Cytogenetics, vol. 125, no. 2, pp. 139-146, 2001.

[134] C. L. Corless, H. Aburatani, J. A. Fletcher, D. E. Housman, M. B. Amin, and D. S. Weinberg, "Papillary renal cell carcinoma: quantitation of chromosomes 7 and 17 by FISH, analysis of chromosome $3 \mathrm{p}$ for LOH, and DNA ploidy," Diagnostic Molecular Pathology, vol. 5, no. 1, pp. 53-64, 1996.

[135] M. Brunelli, J. N. Eble, S. Zhang, G. Martignoni, and L. Cheng, "Gains of chromosomes 7, 17, 12, 16, and 20 and loss of Y occur early in the evolution of papillary renal cell neoplasia: a fluorescent in situ hybridization study," Modern Pathology, vol. 16, no. 10, pp. 1053-1059, 2003.

[136] J. Pailoor, R. Rajandram, N. Y. Yap, K. L. Ng, Z. Wang, and K. R. Iyengar, "Chromosome 7 aneuploidy in clear cell and papillary renal cell carcinoma: detection using silver in situ hybridization technique," Indian Journal of Pathology and Microbiology, vol. 56, no. 2, pp. 98-102, 2013.

[137] T. Klatte, A. J. Pantuck, J. W. Said et al., "Cytogenetic and molecular tumor profiling for type 1 and type 2 papillary renal cell carcinoma," Clinical Cancer Research, vol. 15, no. 4, pp. 1162$1169,2009$.

[138] B. Gunawan, A. Von Heydebreck, T. Fritsch et al., "Cytogenetic and morphologic typing of 58 papillary renal cell carcinomas: evidence for a cytogenetic evolution of type 2 from type 1 tumors," Cancer Research, vol. 63, no. 19, pp. 6200-6205, 2003.

[139] J. Fischer, G. Palmedo, R. Von Knobloch et al., "Duplication and overexpression of the mutant allele of the MET proto-oncogene in multiple hereditary papillary renal cell tumours," Oncogene, vol. 17, no. 6, pp. 733-739, 1998.

[140] Z. Zhuang, W.-S. Park, S. Pack et al., “Trisomy 7-harbouring non-random duplication of the mutant MET allele in hereditary papillary renal carcinomas," Nature Genetics, vol. 20, no. 1, pp. 66-69, 1998.

[141] I. A. Lubensky, L. Schmidt, Z. Zhuang et al., "Hereditary and sporadic papillary renal carcinomas with c-met mutations share a distinct morphological phenotype," American Journal of Pathology, vol. 155, no. 2, pp. 517-526, 1999.

[142] S. L. Organ and M. S. Tsao, "An overview of the c-MET signaling pathway," Therapeutic Advances in Medical Oncology, vol. 3, no. 1, supplement, pp. S7-S19, 2011.

[143] P. Sweeney, A. K. El-Naggar, S.-H. Lin, and L. L. Pisters, "Biological significance of c-met over expression in papillary renal cell carcinoma," Journal of Urology, vol. 168, no. 1, pp. 51$55,2002$. 
[144] S. C. Jong, M. K. Kim, W. S. Jin et al., "MET expression in sporadic renal cell carcinomas," Journal of Korean Medical Science, vol. 21, no. 4, pp. 672-677, 2006.

[145] Y. Miyata, H. Kanetake, and S. Kanda, "Presence of phosphorylated hepatocyte growth factor receptor/c-Met is associated with tumor progression and survival in patients with conventional renal cell carcinoma," Clinical Cancer Research, vol. 12, no. 16, pp. 4876-4881, 2006.

[146] G. T. Gibney, S. A. Aziz, R. L. Camp et al., "c-Met is a prognostic marker and potential therapeutic target in clear cell renal cell carcinoma," Annals of Oncology, vol. 24, no. 2, pp. 343-349, 2013.

[147] T. K. Choueiri, U. Vaishampayan, J. E. Rosenberg et al., "Phase II and biomarker study of the dual MET/VEGFR2 inhibitor foretinib in patients with papillary renal cell carcinoma," Journal of Clinical Oncology, vol. 31, no. 2, pp. 181-186, 2013.

[148] Y.-W. Zhang, "Promise and challenges on the horizon of MET-targeted cancer therapeutics," World Journal of Biological Chemistry, vol. 6, no. 2, pp. 16-27, 2015.

[149] M.-H. Wei, O. Toure, G. M. Glenn et al., "Novel mutations in $\mathrm{FH}$ and expansion of the spectrum of phenotypes expressed in families with hereditary leiomyomatosis and renal cell cancer," Journal of Medical Genetics, vol. 43, no. 1, pp. 18-27, 2006.

[150] R. L. Grubb III, M. E. Franks, J. Toro et al., "Hereditary leiomyomatosis and renal cell cancer: a syndrome associated with an aggressive form of inherited renal cancer," Journal of Urology, vol. 177, no. 6, pp. 2074-2080, 2007.

[151] M. J. Merino, C. Torres-Cabala, P. Pinto, and W. Marston Linehan, "The morphologic spectrum of kidney tumors in hereditary leiomyomatosis and renal cell carcinoma (HLRCC) syndrome," The American Journal of Surgical Pathology, vol. 31, no. 10, pp. 1578-1585, 2007.

[152] J. R. Toro, M. L. Nickerson, M.-H. Wei et al., "Mutations in the fumarate hydratase gene cause hereditary leiomyomatosis and renal cell cancer in families in North America," American Journal of Human Genetics, vol. 73, no. 1, pp. 95-106, 2003.

[153] D. L. Smit, A. R. Mensenkamp, S. Badeloe et al., "Hereditary leiomyomatosis and renal cell cancer in families referred for fumarate hydratase germline mutation analysis," Clinical Genetics, vol. 79, no. 1, pp. 49-59, 2011.

[154] B. Gardie, A. Remenieras, D. Kattygnarath et al., "Novel FH mutations in families with hereditary leiomyomatosis and renal cell cancer (HLRCC) and patients with isolated type 2 papillary renal cell carcinoma," Journal of Medical Genetics, vol. 48, no. 4, pp. 226-234, 2011.

[155] J. S. Isaacs, Y. J. Jung, D. R. Mole et al., "HIF overexpression correlates with biallelic loss of fumarate hydratase in renal cancer: novel role of fumarate in regulation of HIF stability," Cancer Cell, vol. 8, no. 2, pp. 143-153, 2005.

[156] M. Kiuru, R. Lehtonen, J. Arola et al., "Few FH mutations in sporadic counterparts of tumor types observed in hereditary leiomyomatosis and renal cell cancer families," Cancer Research, vol. 62, no. 16, pp. 4554-4557, 2002.

[157] COSMIC Catalogue of somatic mutations in cancer, 2015, http://cancer.sanger.ac.uk/wgs/browse/tissue.

[158] F. Jiang, J. Richter, P. Schraml et al., "Chromosomal imbalances in papillary renal cell carcinoma: genetic differences between histological subtypes," The American Journal of Pathology, vol. 153, no. 5, pp. 1467-1473, 1998.

[159] M. Brunelli, S. Gobbo, P. Cossu-Rocca et al., "Chromosomal gains in the sarcomatoid transformation of chromophobe renal cell carcinoma," Modern Pathology, vol. 20, no. 3, pp. 303-309, 2007.
[160] G. Kovacs, L. Fuzesi, A. Emanuel, and H.-F. Kung, "Cytogenetics of papillary renal cell tumors," Genes Chromosomes and Cancer, vol. 3, no. 4, pp. 249-255, 1991.

[161] M. Kovac, C. Navas, S. Horswell et al., "Recurrent chromosomal gains and heterogeneous driver mutations characterise papillary renal cancer evolution," Nature Communications, vol. 6, article 6336, 2015.

[162] M. C. Jaramillo and D. D. Zhang, "The emerging role of the Nrf2-Keap1 signaling pathway in cancer," Genes \& Development, vol. 27, no. 20, pp. 2179-2191, 2013.

[163] L. E. Moore, M. L. Nickerson, P. Brennan et al., "Von HippelLindau (VHL) inactivation in sporadic clear cell renal cancer: associations with germline VHL polymorphisms and etiologic risk factors," PLoS Genetics, vol. 7, no. 10, Article ID e1002312, 2011.

[164] M. L. Nickerson, E. Jaeger, Y. Shi et al., "Improved identification of von Hippel-Lindau gene alterations in clear cell renal tumors," Clinical Cancer Research, vol. 14, no. 15, pp. 4726-4734, 2008.

[165] R. E. Banks, P. Tirukonda, C. Taylor et al., "Genetic and epigenetic analysis of von Hippel-Lindau (VHL) gene alterations and relationship with clinical variables in sporadic renal cancer," Cancer Research, vol. 66, no. 4, pp. 2000-2011, 2006.

[166] S. Kvasha, V. Gordiyuk, A. Kondratov et al., "Hypermethylation of the $5^{\prime} \mathrm{CpG}$ island of the FHIT gene in clear cell renal carcinomas," Cancer Letters, vol. 265, no. 2, pp. 250-257, 2008.

[167] W.-G. Deng, M. Nishizaki, B. Fang, J. A. Roth, and L. Ji, "Induction of apoptosis by tumor suppressor FHIT via death receptor signaling pathway in human lung cancer cells," Biochemical and Biophysical Research Communications, vol. 355, no. 4, pp. $993-$ 999, 2007.

[168] J. C. Saldivar, H. Shibata, and K. Huebner, "Pathology and biology associated with the fragile FHIT gene and gene product," Journal of Cellular Biochemistry, vol. 109, no. 5, pp. 858-865, 2010.

[169] C. Sevignani, G. A. Calin, R. Cesari et al., "Restoration of fragile histidine triad (FHIT) expression induces apoptosis and suppresses tumorigenicity in breast cancer cell lines," Cancer Research, vol. 63, no. 6, pp. 1183-1187, 2003.

[170] L. Roz, M. Gramegna, H. Ishii, C. M. Croce, and G. Sozzi, "Restoration of fragile histidine triad (FHIT) expression induces apoptosis and suppresses tumorigenicity in lung and cervical cancer cell lines," Proceedings of the National Academy of Sciences of the United States of America, vol. 99, no. 6, pp. 3615-3620, 2002.

[171] K. Dreijerink, E. Braga, I. Kuzmin et al., "The candidate tumor suppressor gene, RASSF1A, from human chromosome 3p21.3 is involved in kidney tumorigenesis," Proceedings of the National Academy of Sciences of the United States of America, vol. 98, no. 13, pp. 7504-7509, 2001.

[172] C. Simone, "SWI/SNF: the crossroads where extracellular signaling pathways meet chromatin," Journal of Cellular Physiology, vol. 207, no. 2, pp. 309-314, 2006.

[173] J.-H. Park, E.-J. Park, S.-K. Hur, S. Kim, and J. Kwon, "Mammalian SWI/SNF chromatin remodeling complexes are required to prevent apoptosis after DNA damage," DNA Repair, vol. 8, no. 1, pp. 29-39, 2009.

[174] Z. M. Eletr and K. D. Wilkinson, "An emerging model for BAPl's role in regulating cell cycle progression," Cell Biochemistry and Biophysics, vol. 60, no. 1-2, pp. 3-11, 2011.

[175] G. Duns, E. D. van Berg, I. van Duivenbode et al., "Histone methyltransferase gene SETD2 is a novel tumor suppressor gene 
in clear cell renal cell carcinoma," Cancer Research, vol. 70, no. 11, pp. 4287-4291, 2010.

[176] X. Niu, T. Zhang, L. Liao et al., "The von Hippel-Lindau tumor suppressor protein regulates gene expression and tumor growth through histone demethylase JARID1C," Oncogene, vol. 31, no. 6, pp. 776-786, 2012.

[177] D. Schullerus, R. von Knobloch, J. Chudek, J. Herbers, and G. Kovacs, "Microsatellite analysis reveals deletion of a large region at chromosome $8 \mathrm{p}$ in conventional renal cell carcinoma," International Journal of Cancer, vol. 80, no. 1, pp. 22-24, 1999.

[178] K. Mitsumori, J. M. Kittleson, N. Itoh et al., "Chromosome 14q LOH in localized clear cell renal cell carcinoma," Journal of Pathology, vol. 198, no. 1, pp. 110-114, 2002.

[179] A. Alimov, B. Sundelin, N. Wang, C. Larsson, and U. Bergerheim, "Loss of 14q31-q32.2 in renal cell carcinoma is associated with high malignancy grade and poor survival," International Journal of Oncology, vol. 25, no. 1, pp. 179-185, 2004.

[180] H. Kaku, S. Ito, S. Ebara et al., "Positive correlation between allelic loss at chromosome 14q24-31 and poor prognosis of patients with renal cell carcinoma," Urology, vol. 64, no. 1, pp. 176-181, 2004.

[181] J. An, J. Choi, B. K. Shin, A. Kim, H. K. Kim, and I. Kim, "Chromogenic in situ hybridization detection of chromosome 7 and 17 abnormalities in renal cell carcinomas and comparison to flow cytometric DNA ploidy patterns," Basic and Applied Pathology, vol. 1, no. 2, pp. 66-71, 2008.

[182] D. J. Lager, B. J. Huston, T. G. Timmerman, and S. M. Bonsib, "Papillary renal tumors: morphologic, cytochemical, and genotypic features," Cancer, vol. 76, no. 4, pp. 669-673, 1995.

[183] M. D. Hughson, K. Dickman, S. A. Bigler, A. M. Meloni, and A. A. Sandberg, "Clear-cell and papillary carcinoma of the kidney: an analysis of chromosome 3, 7, and 17 abnormalities by microsatellite amplification, cytogenetics, and fluorescence in situ hybridization," Cancer Genetics and Cytogenetics, vol. 106, no. 2, pp. 93-104, 1998.

[184] W. Yu, W. Zhang, Y. Jiang et al., "Clinicopathological, genetic, ultrastructural characterizations and prognostic factors of papillary renal cell carcinoma: new diagnostic and prognostic information," Acta Histochemica, vol. 115, no. 5, pp. 452-459, 2013.

[185] M. E. Sanders, R. Mick, J. E. Tomaszewski, and F. G. Barr, "Unique patterns of allelic imbalance distinguish type 1 from type 2 sporadic papillary renal cell carcinoma," The American Journal of Pathology, vol. 161, no. 3, pp. 997-1005, 2002.

[186] X. J. Yang, M. H. Tan, H. L. Kim et al., "A molecular classification of papillary renal cell carcinoma," Cancer Research, vol. 65, no. 13, pp. 5628-5637, 2005.

[187] R. F. Schwerdtle, S. Storkel, C. Neuhaus et al., "Allelic losses at chromosomes 1p, 2p, 6p, 10p, 13q, 17p, and 21q significantly correlate with the chromophobe subtype of renal cell carcinoma," Cancer Research, vol. 56, no. 13, pp. 2927-2930, 1996.

[188] A. Nagy, I. Buzogany, and G. Kovacs, "Microsatellite allelotyping differentiates chromophobe renal cell carcinomas from renal oncocytomas and identifies new genetic changes," Histopathology, vol. 44, no. 6, pp. 542-546, 2004.

[189] M. Brunelli, J. N. Eble, S. Zhang, G. Martignoni, B. Delahunt, and L. Cheng, "Eosinophilic and classic chromophobe renal cell carcinomas have similar frequent losses of multiple chromosomes from among chromosomes 1, 2, 6, 10, and 17, and this pattern of genetic abnormality is not present in renal oncocytoma," Modern Pathology, vol. 18, no. 2, pp. 161-169, 2005.
[190] M. Sperga, P. Martinek, T. Vanecek et al., "Chromophobe renal cell carcinoma-chromosomal aberration variability and its relation to Paner grading system: an array CGH and FISH analysis of 37 cases," Virchows Archiv, vol. 463, no. 4, pp. 563573, 2013.

[191] S. Gad, S. H. Lefèvre, S. K. Khoo et al., "Mutations in BHD and TP53 genes, but not in HNF1beta gene, in a large series of sporadic chromophobe renal cell carcinoma," British Journal of Cancer, vol. 96, no. 2, pp. 336-340, 2007.

[192] C. Davis, C. J. Ricketts, M. Wang et al., "The somatic genomic landscape of chromophobe renal cell carcinoma," Cancer Cell, vol. 26, no. 3, pp. 319-330, 2014.

[193] H. Contractor, M. Zariwala, P. Bugert, J. Zeisler, and G. Kovacs, "Mutation of the p53 tumour suppressor gene occurs preferentially in the chromophobe type of renal cell tumour," Journal of Pathology, vol. 181, no. 2, pp. 136-139, 1997.

[194] M. M. Picken, B. Chyna, R. C. Flanigan, and J. M. Lee, "Analysis of chromosome 1p abnormalities in renal oncocytomas by loss of heterozygosity studies: correlation with conventional cytogenetics and fluorescence in situ hybridization," American Journal of Clinical Pathology, vol. 129, no. 3, pp. 377-382, 2008.

[195] V. Lindgren, G. P. Paner, A. Omeroglu et al., "Cytogenetic analysis of a series of 13 renal oncocytomas," Journal of Urology, vol. 171, no. 2, pp. 602-604, 2004.

[196] J. A. Brown, S. Takahashi, A. Alcaraz et al., "Fluorescence in situ hybridization analysis of renal oncocytoma reveals frequent loss of chromosomes Y and 1," Journal of Urology, vol. 156, no. 1, pp. 31-35, 1996.

[197] L. Füzesi, D. Frank, C. Nguyen, R.-H. Ringert, H. Bartels, and B. Gunawan, "Losses of $1 p$ and chromosome 14 in renal oncocytomas," Cancer Genetics and Cytogenetics, vol. 160, no. 2, pp. 120-125, 2005.

[198] W. R. Sukov, R. P. Ketterling, D. J. Lager et al., "CCND1 rearrangements and cyclin D1 overexpression in renal oncocytomas: frequency, clinicopathologic features, and utility in differentiation from chromophobe renal cell carcinoma," Human Pathology, vol. 40, no. 9, pp. 1296-1303, 2009.

[199] E. Van Den Berg, T. Dijkhuizen, S. Störkel et al., "Chromosomal changes in renal oncocytomas: evidence that $\mathrm{t}(5 ; 11)(\mathrm{q} 35 ; \mathrm{q} 13)$ may characterize a second subgroup of oncocytomas," Cancer Genetics and Cytogenetics, vol. 79, no. 2, pp. 164-168, 1995.

[200] L. Fuzesi, B. Gunawan, S. Braun et al., "Cytogenetic analysis of 11 renal oncocytomas: further evidence of structural rearrangements of 11q13 as a characteristic chromosomal anomaly," Cancer Genetics and Cytogenetics, vol. 107, no. 1, pp. 1-6, 1998.

[201] F. Becker, K. Junker, M. Parr et al., "Collecting duct carcinomas represent a unique tumour entity based on genetic alterations," PLoS ONE, vol. 8, no. 10, Article ID e78137, 2013.

[202] L. Fuzesi, M. Cober, and C. Mittermayer, "Collecting duct carcinoma: cytogenetic characterization," Histopathology, vol. 21, no. 2, pp. 155-160, 1992.

[203] L. S. Schmidt and W. M. Linehan, "Hereditary leiomyomatosis and renal cell carcinoma," International Journal of Nephrology and Renovascular Disease, vol. 7, pp. 253-260, 2014.

[204] C. P. Pavlovich, R. L. Grubb III, K. Hurley et al., "Evaluation and management of renal tumors in the Birt-Hogg-Dubé syndrome," The Journal of Urology, vol. 173, no. 5, pp. 1482-1486, 2005.

[205] L. S. Schmidt, M. L. Nickerson, M. B. Warren et al., "Germline BHD-mutation spectrum and phenotype analysis of a large 
cohort of families with Birt-Hogg-Dubé syndrome," The American Journal of Human Genetics, vol. 76, no. 6, pp. 1023-1033, 2005.

[206] C. P. Pavlovich, M. M. Walther, R. A. Eyler et al., "Renal tumors in the Birt-Hogg-Dubé syndrome," The American Journal of Surgical Pathology, vol. 26, no. 12, pp. 1542-1552, 2002.

[207] A. Szponar, M. V. Yusenko, and G. Kovacs, "High-resolution array CGH of metanephric adenomas: lack of DNA copy number changes," Histopathology, vol. 56, no. 2, pp. 212-216, 2010.

[208] R. Drut, R. M. Drut, and C. Ortolani, "Metastatic metanephric adenoma with foci of papillary carcinoma in a child: a combined histologic, immunohistochemical, and FISH study," International Journal of Surgical Pathology, vol. 9, no. 3, pp. 241-247, 2001.

[209] A. A. Renshaw, D. R. Freyer, and Y. A. Hammers, "Metastatic metanephric adenoma in a child," American Journal of Surgical Pathology, vol. 24, no. 4, pp. 570-574, 2000.

[210] J. A. Brown, K. L. Anderl, T. J. Borell, J. Qian, D. G. Bostwick, and R. B. Jenkins, "Simultaneous chromosome 7 and 17 gain and sex chromosome loss provide evidence that renal metanephric adenoma is related to papillary renal cell carcinoma," Journal of Urology, vol. 158, no. 2, pp. 370-374, 1997.

[211] C.-C. Pan and J. I. Epstein, "Detection of chromosome copy number alterations in metanephric adenomas by array comparative genomic hybridization," Modern Pathology, vol. 23, no. 12, pp. 1634-1640, 2010.

[212] M. Brunelli, J. N. Eble, S. Zhang, G. Martignoni, and L. Cheng, "Metanephric adenoma lacks the gains of chromosomes 7 and 17 and loss of $Y$ that are typical of papillary renal cell carcinoma and papillary adenoma," Modern Pathology, vol. 16, no. 10, pp. 1060-1063, 2003.

[213] M. Stumm, A. Koch, P. F. Wieacker et al., "Partial monosomy $2 \mathrm{p}$ as the single chromosomal anomaly in a case of renal metanephric adenoma," Cancer Genetics and Cytogenetics, vol. 115, no. 1, pp. 82-85, 1999.

[214] T. Pesti, F. Sükösd, E. C. Jones, and G. Kovacs, "Mapping a tumor suppressor gene to chromosome 2p13 in metanephric adenoma by microsatellite allelotyping," Human Pathology, vol. 32, no. 1 , pp. 101-104, 2001.

[215] B. Dadone, D. Ambrosetti, X. Carpentier et al., "A renal metanephric adenoma showing both a 2p16-24 deletion and BRAF V600E mutation: a synergistic role for a tumor suppressor gene on chromosome $2 \mathrm{p}$ and BRAF activation?" Cancer Genetics, vol. 206, no. 9-10, pp. 347-352, 2013.

[216] T. K. Choueiri, J. Cheville, E. Palescandolo et al., "BRAF mutations in metanephric adenoma of the kidney," European Urology, vol. 62, no. 5, pp. 917-922, 2012.

[217] S. Gattenlöhner, B. Etschmann, H. Riedmiller, and H.-K. Müller-Hermelink, "Lack of KRAS and BRAF mutation in renal cell carcinoma," European Urology, vol. 55, no. 6, pp. 1490-1491, 2009.

[218] A. Nagy, I. Balint, and G. Kovacs, "Frequent allelic changes at chromosome 7q34 but lack of mutation of the BRAF in papillary renal cell tumors," International Journal of Cancer, vol. 106, no. 6, pp. 980-981, 2003.

[219] E. W. Joseph, C. A. Pratilas, P. I. Poulikakos et al., "The RAF inhibitor PLX4032 inhibits ERK signaling and tumor cell proliferation in a V600E BRAF-selective manner," Proceedings of the National Academy of Sciences of the United States of America, vol. 107, no. 33, pp. 14903-14908, 2010.
[220] J. N. Eble, Pathology and Genetics of Tumours of the Urinary System and Male Genital Organs, IARC, 2004.

[221] S. S. Shen, J. Y. Ro, P. Tamboli et al., "Mucinous tubular and spindle cell carcinoma of kidney is probably a variant of papillary renal cell carcinoma with spindle cell features," Annals of Diagnostic Pathology, vol. 11, no. 1, pp. 13-21, 2007.

[222] P. Cossu-Rocca, J. N. Eble, B. Delahunt et al., "Renal mucinous tubular and spindle carcinoma lacks the gains of chromosomes 7 and 17 and losses of chromosome $\mathrm{Y}$ that are prevalent in papillary renal cell carcinoma," Modern Pathology, vol. 19, no. 4, pp. 488-493, 2006.

[223] N. Kuroda, T. Naroda, M. Tamura et al., "High-grade mucinous tubular and spindle cell carcinoma: comparative genomic hybridization study," Annals of Diagnostic Pathology, vol. 15, no. 6, pp. 472-475, 2011.

[224] P. Brandal, A. K. Lie, A. Bassarova et al., "Genomic aberrations in mucinous tubular and spindle cell renal cell carcinomas," Modern Pathology, vol. 19, no. 2, pp. 186-194, 2006.

[225] K. Okoń, A. Klimkowska, A. Pawelec, Z. Dobrowolski, Z. Kohla, and J. Stachura, "Immunophenotype and cytogenetics of mucinous tubular and spindle cell carcinoma of the kidney," Polish Journal of Pathology, vol. 58, no. 4, pp. 227-233, 2007.

[226] Y. Zhang, X. Yong, Q. Wu et al., "Mucinous tubular and spindle cell carcinoma and solid variant papillary renal cell carcinoma: a clinicopathologic comparative analysis of four cases with similar molecular genetics datum," Diagnostic Pathology, vol. 9, no. 1, article 194, 2014.

[227] C. Rakozy, G. E. Schmahl, S. Bogner, and S. Störkel, "Low-grade tubular-mucinous renal neoplasms: morphologic, immunohistochemical, and genetic features," Modern Pathology, vol. 15, no. 11, pp. 1162-1171, 2002.

[228] P. Argani, S. Olgac, S. K. Tickoo et al., "Xp11 Translocation renal cell carcinoma in adults: expanded clinical, pathologic, and genetic spectrum," American Journal of Surgical Pathology, vol. 31, no. 8, pp. 1149-1160, 2007.

[229] Y. Komai, M. Fujiwara, Y. Fujii et al., "Adult Xp11 translocation renal cell carcinoma diagnosed by cytogenetics and immunohistochemistry," Clinical Cancer Research, vol. 15, no. 4, pp. 1170-1176, 2009.

[230] H. B. Armah and A. V. Parwani, "Xp11.2 translocation renal cell carcinoma," Archives of Pathology and Laboratory Medicine, vol. 134, no. 1, pp. 124-129, 2010.

[231] P. Ahluwalia, B. Nair, and G. Kumar, "Renal cell carcinoma associated with Xp11.2 translocation/TFE3 gene fusion: a rare case report with review of the literature," Case Reports in Urology, vol. 2013, Article ID 810590, 4 pages, 2013.

[232] P. Argani, P. Lal, B. Hutchinson, M. Y. Lui, V. E. Reuter, and M. Ladanyi, "Aberrant nuclear immunoreactivity for TFE3 in neoplasms with TFE3 gene fusions: a sensitive and specific immunohistochemical assay," The American Journal of Surgical Pathology, vol. 27, no. 6, pp. 750-761, 2003.

[233] C. G. Przybycin, A. M. Cronin, F. Darvishian et al., "Chromophobe renal cell carcinoma: a clinicopathologic study of 203 tumors in 200 patients with primary resection at a single institution," The American Journal of Surgical Pathology, vol. 35, no. 7, pp. 962-970, 2011.

[234] S. D. W. Beck, M. I. Patel, M. E. Snyder et al., "Effect of papillary and chromophobe cell type on disease-free survival after nephrectomy for renal cell carcinoma," Annals of Surgical Oncology, vol. 11, no. 1, pp. 71-77, 2004.

[235] M. B. Amin, G. P. Paner, I. Alvarado-Cabrero et al., "Chromophobe renal cell carcinoma: Histomorphologic characteristics 
and evaluation of conventional pathologic prognostic parameters in 145 cases," American Journal of Surgical Pathology, vol. 32, no. 12, pp. 1822-1834, 2008.

[236] M. L. Nickerson, M. B. Warren, J. R. Toro et al., "Mutations in a novel gene lead to kidney tumors, lung wall defects, and benign tumors of the hair follicle in patients with the Birt-Hogg-Dubé syndrome," Cancer Cell, vol. 2, no. 2, pp. 157-164, 2002.

[237] M. B. Warren, C. A. Torres-Cabala, M. L. Turner et al., "Expression of Birt-Hogg-Dube gene mRNA in normal and neoplastic human tissues," Modern Pathology, vol. 17, no. 8, pp. 998-1011, 2004.

[238] C. D. Vocke, Y. Yang, C. P. Pavlovich et al., "High frequency of somatic frameshift BHD gene mutations in Birt-HoggDubé-associated renal tumors," Journal of the National Cancer Institute, vol. 97, no. 12, pp. 931-935, 2005.

[239] J. Chen, K. Futami, D. Petillo et al., "Deficiency of FLCN in mouse kidney led to development of polycystic kidneys and renal neoplasia," PLoS ONE, vol. 3, no. 10, Article ID e3581, 2008.

[240] M. Baba, M. Furihata, S.-B. Hong et al., "Kidney-targeted BirtHogg-Dubé gene inactivation in a mouse model: Erk1/2 and Akt-mTOR activation, cell hyperproliferation, and polycystic kidneys," Journal of the National Cancer Institute, vol. 100, no. 2, pp. 140-154, 2008.

[241] A. Nagy, D. Zoubakov, Z. Stupar, and G. Kovacs, "Lack of mutation of the folliculin gene in sporadic chromophobe renal cell carcinoma and renal oncocytoma," International Journal of Cancer, vol. 109, no. 3, pp. 472-475, 2004.

[242] T. Murakami, F. Sano, Y. Huang et al., "Identification and characterization of Birt-Hogg-Dubé associated renal carcinoma," Journal of Pathology, vol. 211, no. 5, pp. 524-531, 2007.

[243] M. Brunelli, B. Delahunt, S. Gobbo et al., "Diagnostic usefulness of fluorescent cytogenetics in differentiating chromophobe renal cell carcinoma from renal oncocytoma: a validation study combining metaphase and interphase analyses," American Journal of Clinical Pathology, vol. 133, no. 1, pp. 116-126, 2010.

[244] M. V. Yusenko, R. P. Kuiper, T. Boethe et al., "High-resolution DNA copy number and gene expression analyses distinguish chromophobe renal cell carcinomas and renal oncocytomas," BMC Cancer, vol. 9, article 152, 2009.

[245] D. P. Liu, H. Song, and Y. Xu, "A common gain of function of p53 cancer mutants in inducing genetic instability," Oncogene, vol. 29, no. 7, pp. 949-956, 2010.

[246] F. Sükösd, B. Digon, J. Fischer, T. Pietsch, and G. Kovacs, "Allelic loss at 10q23.3 but lack of mutation of PTEN/MMAC1 in chromophobe renal cell carcinoma," Cancer Genetics and Cytogenetics, vol. 128, no. 2, pp. 161-163, 2001.

[247] G. P. Paner, M. B. Amin, I. Alvarado-Cabrero et al., "A novel tumor grading scheme for chromophobe renal cell carcinoma: prognostic utility and comparison with fuhrman nuclear grade," The American Journal of Surgical Pathology, vol. 34, no. 9, pp. 1233-1240, 2010.

[248] M. H. Tan, C. F. Wong, H. L. Tan et al., "Genomic expression and single-nucleotide polymorphism profiling discriminates chromophobe renal cell carcinoma and oncocytoma," $B M C$ Cancer, vol. 10, article 196, 2010.

[249] J. D. Oxley, J. Sullivan, A. Mitchelmore, and D. A. Gillatt, "Metastatic renal oncocytoma," Journal of Clinical Pathology, vol. 60 , no. 6, pp. 720-722, 2007.
[250] J. S. Jhang, G. Narayan, V. V. V. S. Murty, and M. M. Mansukhani, "Renal oncocytomas with 1lq13 rearrangements: cytogenetic, molecular, and immunohistochemical analysis of cyclin D1," Cancer Genetics and Cytogenetics, vol. 149, no. 2, pp. 114-119, 2004.

[251] S. Zanssen, B. Gunawan, L. Fuzesi, D. Warburton, and E. A. Schon, "Renal oncocytomas with rearrangements involving $11 q 13$ contain breakpoints near CCND1," Cancer Genetics and Cytogenetics, vol. 149, no. 2, pp. 120-124, 2004.

[252] T. Dijkhuizen, E. van den Berg, S. Storkel et al., "Renal oncocytoma with $\mathrm{t}(5 ; 12 ; 11)$, der(1)1;8) and add(19): 'true' oncocytoma or chromophobe adenoma?" International Journal of Cancer, vol. 73, no. 4, pp. 521-524, 1997.

[253] N. Tokuda, S. Naito, O. Matsuzaki, Y. Nagashima, S. Ozono, and T. Igarashi, "Collecting duct (Bellini duct) renal cell carcinoma: a nationwide survey in Japan," The Journal of Urology, vol. 176, no. 1, pp. 40-43, 2006.

[254] M. May, V. Ficarra, S. F. Shariat et al., "Impact of clinical and histopathological parameters on disease specific survival in patients with collecting duct renal cell carcinoma: development of a disease specific risk model," Journal of Urology, vol. 190, no. 2, pp. 458-463, 2013.

[255] M. Schoenberg, P. Cairns, J. D. Brooks et al., "Frequent loss of chromosome arms $8 \mathrm{p}$ and $13 \mathrm{q}$ in collecting duct carcinoma (CDC) of the kidney," Genes Chromosomes and Cancer, vol. 12, no. 1, pp. 76-80, 1995.

[256] G. Steiner, P. Cairns, T. J. Polascik et al., "High-density mapping of chromosomal arm $1 \mathrm{q}$ in renal collecting duct carcinoma: region of minimal deletion at 1q32.1-32.2," Cancer Research, vol. 56, no. 21, pp. 5044-5046, 1996.

[257] A. Orsola, I. Trias, C. X. Raventós, I. Español, L. Cecchini, and I. Orsola, "Renal collecting (Bellini) duct carcinoma displays similar characteristics to upper tract urothelial cell carcinoma," Urology, vol. 65, no. 1, pp. 49-54, 2005.

[258] R. Gupta, A. Billis, R. B. Shah et al., "Carcinoma of the collecting ducts of bellini and renal medullary carcinoma: clinicopathologic analysis of 52 cases of rare aggressive subtypes of renal cell carcinoma with a focus on their interrelationship," American Journal of Surgical Pathology, vol. 36, no. 9, pp. 12651278, 2012.

[259] M. A. Swartz, J. Karth, D. T. Schneider, R. Rodriguez, J. B. Beckwith, and E. J. Perlman, "Renal medullary carcinoma: clinical, pathologic, immunohistochemical, and genetic analysis with pathogenetic implications," Urology, vol. 60, no. 6, pp. 10831089, 2002.

[260] Z. Gatalica, S. L. Lilleberg, F. A. Monzon et al., "Renal medullary carcinomas: histopathologic phenotype associated with diverse genotypes," Human Pathology, vol. 42, no. 12, pp. 1979-1988, 2011.

[261] M. B. Amin, G. T. MacLennan, R. Gupta et al., "Tubulocystic carcinoma of the kidney: clinicopathologic analysis of 31 cases of a distinctive rare subtype of renal cell carcinoma," The American Journal of Surgical Pathology, vol. 33, no. 3, pp. 384392, 2009.

[262] G. T. Maclennan, G. M. Farrow, and D. G. Bostwick, "Low-grade collecting duct carcinoma of the kidney: report of 13 cases of low-grade mucinous tubulocystic renal carcinoma of possible collecting duct origin," Urology, vol. 50, no. 5, pp. 679-684, 1997.

[263] M. Zhou, X. J. Yang, J. I. Lopez et al., "Renal tubulocystic carcinoma is closely related to papillary renal cell carcinoma: 
implications for pathologic classification," American Journal of Surgical Pathology, vol. 33, no. 12, pp. 1840-1849, 2009.

[264] T. O. Al-Hussain, L. Cheng, S. Zhang, and J. I. Epstein, "Tubulocystic carcinoma of the kidney with poorly differentiated foci: a series of 3 cases with fluorescence in situ hybridization analysis," Human Pathology, vol. 44, no. 7, pp. 1406-1411, 2013. 


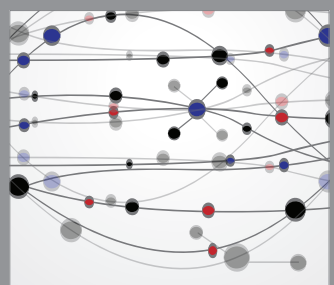

The Scientific World Journal
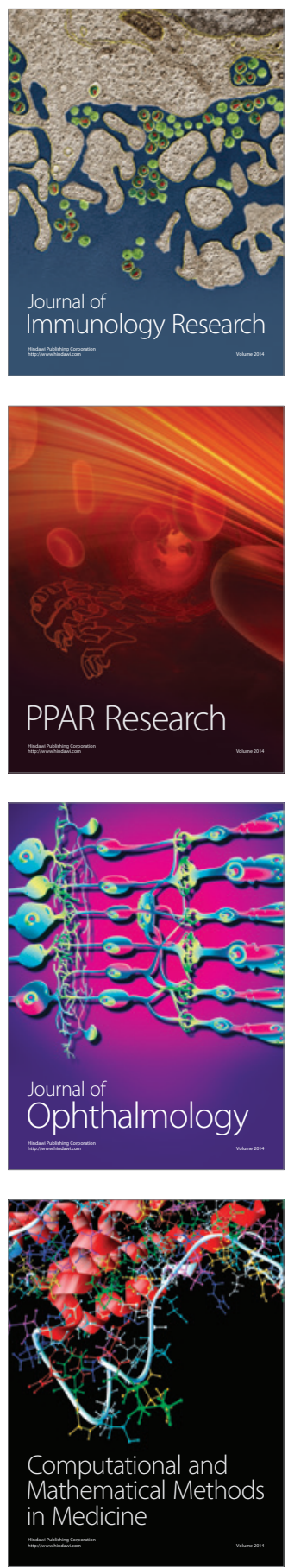

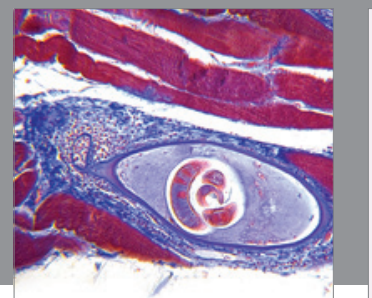

Gastroenterology

Research and Practice
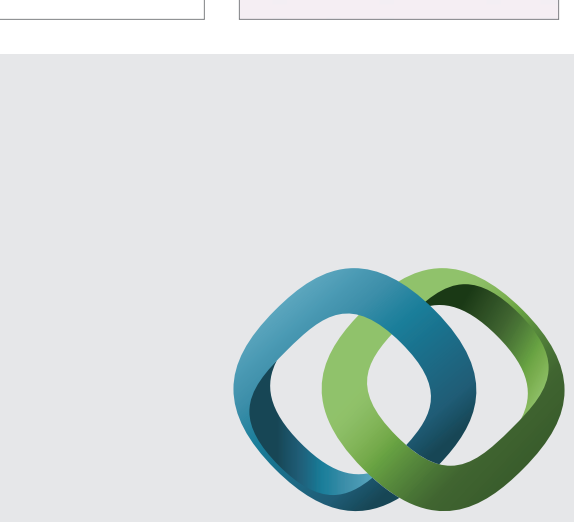

\section{Hindawi}

Submit your manuscripts at

http://www.hindawi.com
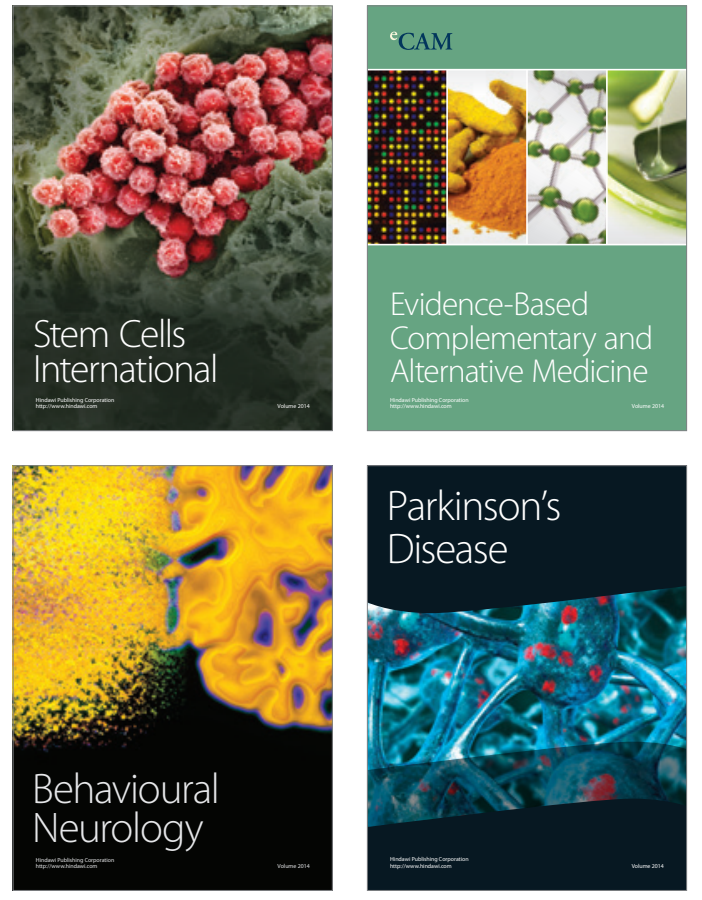
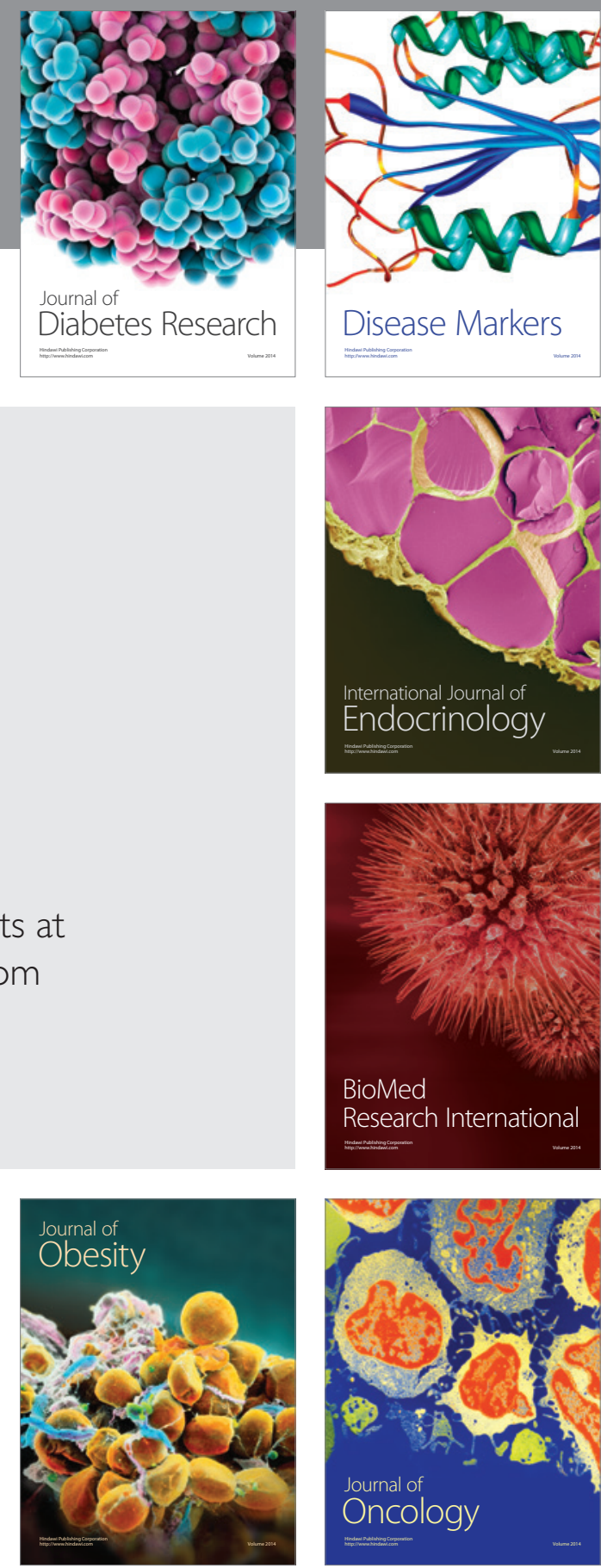

Disease Markers
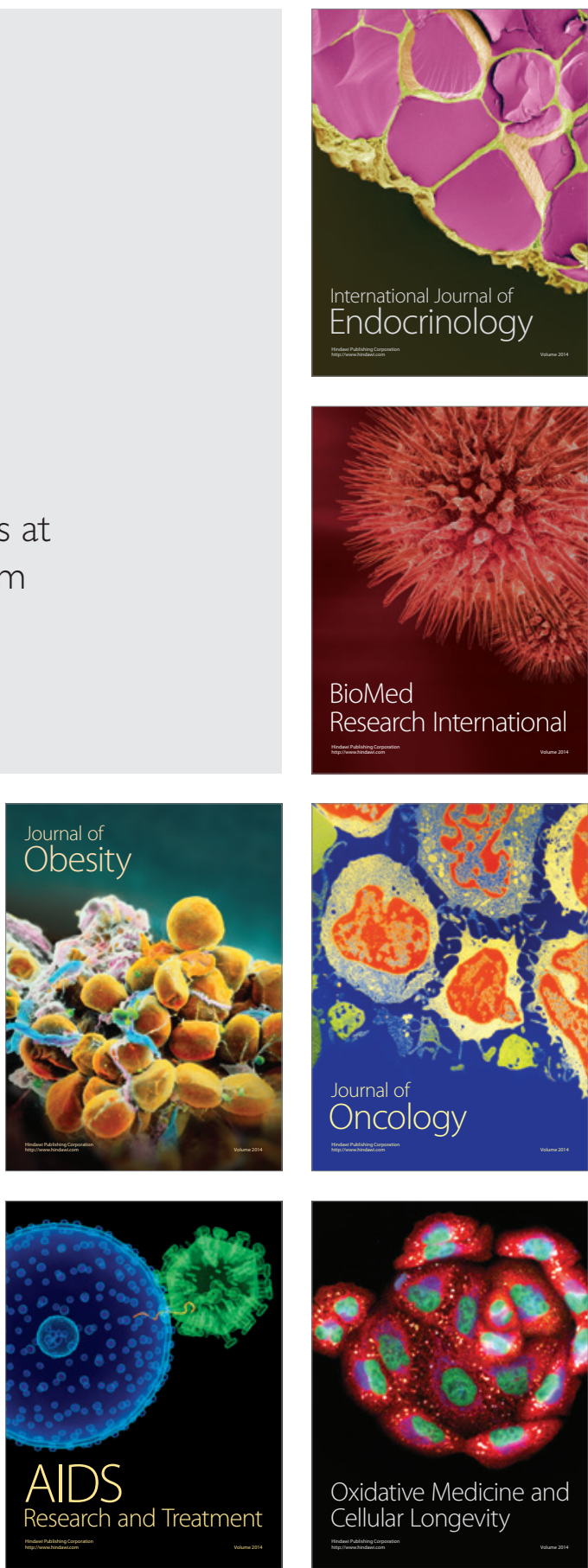